Portland State University

PDXScholar

\title{
A study of the role of the secondary virtues in Uli der Knecht
}

Roland Minder

Portland State University

Follow this and additional works at: https://pdxscholar.library.pdx.edu/open_access_etds

Part of the German Literature Commons

Let us know how access to this document benefits you.

\section{Recommended Citation}

Minder, Roland, "A study of the role of the secondary virtues in Uli der Knecht" (1986). Dissertations and Theses. Paper 3594.

https://doi.org/10.15760/etd.5478

This Thesis is brought to you for free and open access. It has been accepted for inclusion in Dissertations and Theses by an authorized administrator of PDXScholar. Please contact us if we can make this document more accessible: pdxscholar@pdx.edu. 
AN ABSTRACT OF THE THESIS OF Roland Minder for the Master of Arts in German presented liay 6, 1986.

Title: A Study of the Role of the Secondary Virtues in Uli der Knecht. APPROVED BY NEMBERS OF THE THESIS COMITTEE:

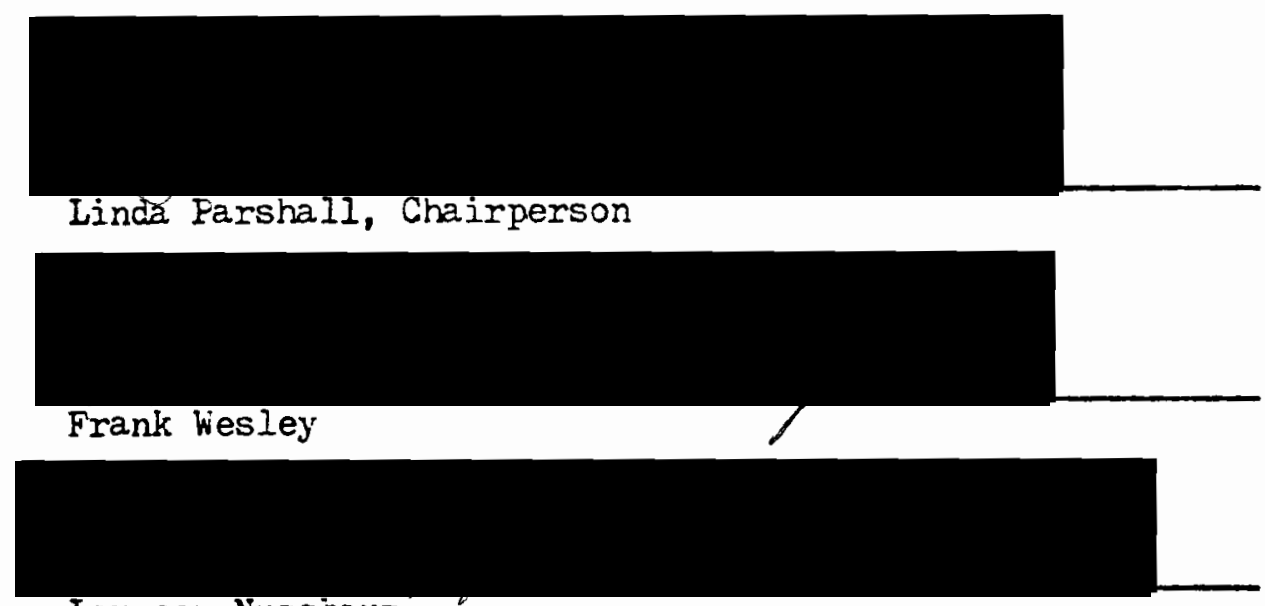

Laureen Nusscaum

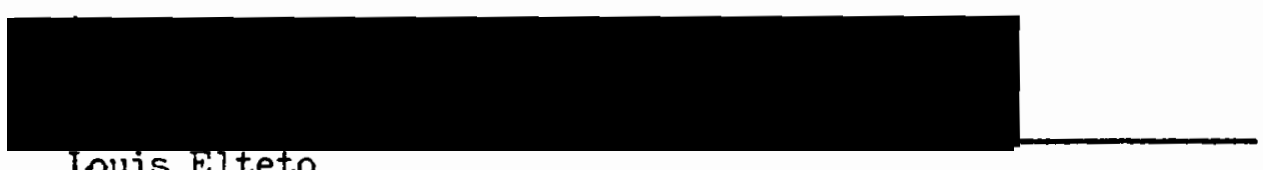

The thesis is a response to critics who interpreted Uli as being too "worldly." Specifically, it attempts to show, by way of exploring the role of a particular category of virtues present in the novel, how these critics misunderstood the novel as well as the intent of the author.

Following an introduction to the topic and problem of the thesis, two approaches are used in proving the thesis. In both, the virtues have been categorized into two distinct groups. One group, the 
traditional theological virtues of faith, hope, and charity have been categorized with the term "primary virtues", basing their supremacy to other virtues on Christian doctrine and tradition. The second group includes all the remaining virtues, categorized with the term "secondary virtues."

The first approach is to use the text-immanent method of interpretation to show how the role of the secondary virtues has been misunderstood by certain critics. It examines the function and relevance of these virtues as they relate to the author's stated intentions and his actual product, the novel itself.

The other approach is to attempt to prove the thesis from a larger context, drawing upon secondary literature. Gotthelf's position in and on aesthetics, his views on matter and the material world, the influence of Biblical ethic and doctrine are all addressed in light of the role and function of the secondary virtues.

By examining the text, it was found that through the practice of certain secondary virtues, Uli acquires material well-being and respect. There is also, simultaneously, a spiritual level to the novel which some of his critics did not acknowledge or recognize. There appears an unmistakable correlation between Uli's material and spiritual progress.

It is found that Gotthelf's God is directly and immediately involved in human affairs and that the practice of the secondary virtues allows for a unification with God and eventual salvation. The practice of the secondary virtues is reenforced by material reward. At the same time, they help in acquiring patterns of behavior which 
allow one to interact positively with one's fellow man and allow one to experience primary virtues. Faith is increased as one sees empirical proof of progress through thrift. Love is increased as loyalty develops. Hope is kindled as one is industrious in pursuit of betterment. These virtues continually reenforce ech other and lead to a unity with a God that rewards virtuous behavior here and now, as well as in a later after-life.

It was this "sanctification process", which many have written about already, which was misunderstood by Gotthelf's aforementioned critics. This process is depicted in Uli. 
A STUDY OF THE ROLE OF THE SECONDASY VTRTUS

IN ULY DER KIECIT

by

ROIAND MINDER

A thesis subnitted in partial fulfillment of the requirements for the desree of

\author{
MASTER OF ARTS \\ in \\ GERMAN
}

Portland State University

1986 
TO THE OFFICE OF GRADUATE STUDIES AND RESEARCH:

The members of the Committee approve the thesis of Roland Minder presented May 6, 1986.

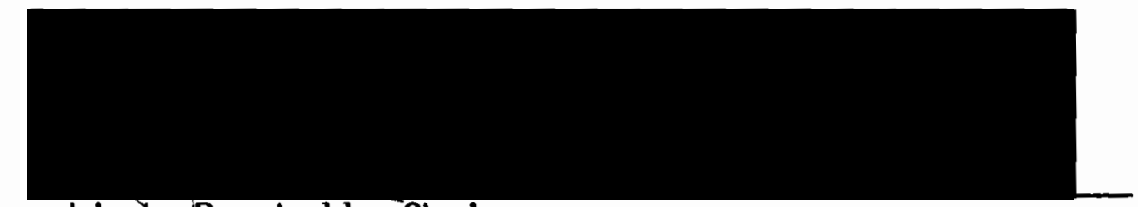

Linda Parshall, Chairperson

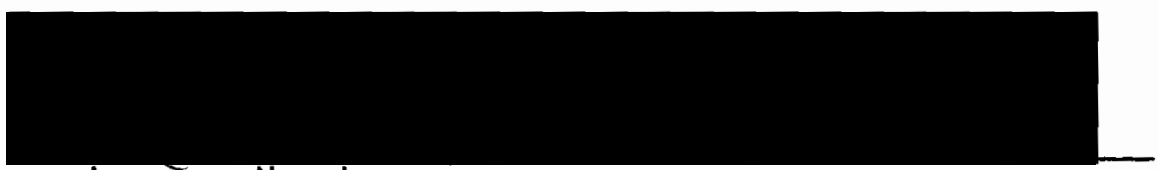

Laureen Nussbaum

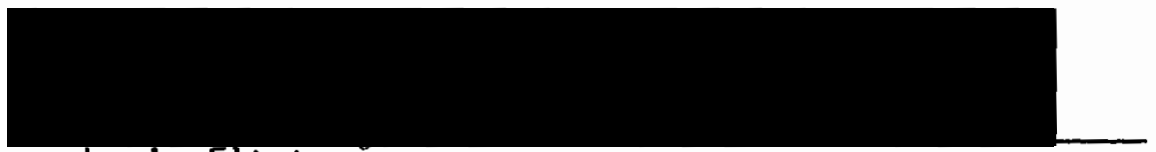

Louis Elteto

APPROVED :

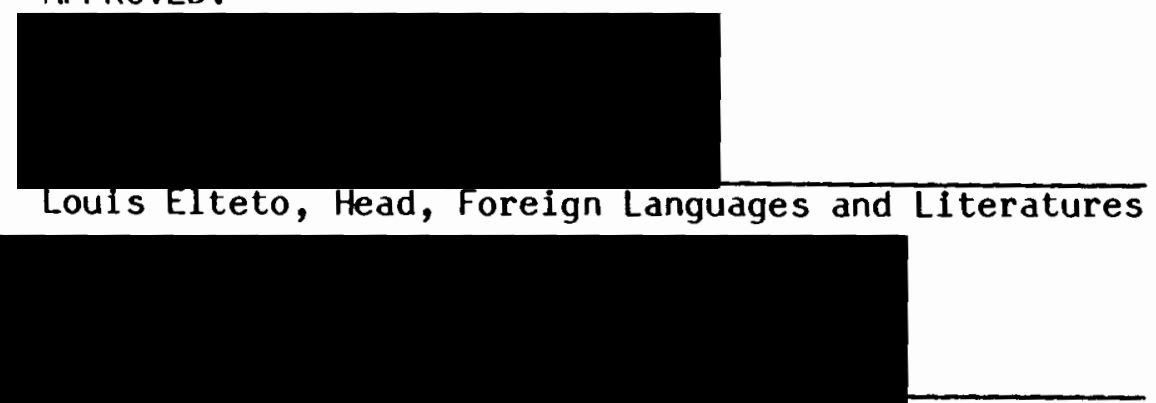

bernard koss, vean of Graduate studies 


\section{ACKNOWLEDGEMENTS}

As is the case with all of us, no man is an island and no work of any individual can disclaim the help and influence of others. I must, therefore, out of a sincere feeling of gratitude, make mention of such people as they relate to this work.

Foremost in my mind is the thanks I owe my wife, jeanette, for the unrelenting support and understanding she has given me in completing this task. The time I have deprived my children of must also be acknowleded. Finally, the stylistic and organizational advice of Dr. Linda B. Parshall has contributed much to the completion of this thesis and is greatly appreciated. 
TABIE OF CONTENTS

PAGE

ACKNOWLEDGEMENTS . . ....................... i1i

\section{CHA PTER}

I EACKGROUND ....................... 1

II THE TEXT ...................... 13

II COMMENARY . . . . . . . . . . . . . . . . 50

Genre and Aesthetics . . . . . . . . 50

Antimaterialism .............. 61

Secondary Virtues Vis-a-vis Selfishness

Secondary Virtues Vis-a-vis Avarice

Secondary Virtues Vis-a-vis Materialism

Biblical Ethik and Doctrine ... . . . . . 74

The Sanctification Process

Work and Acquisition

The Economy

Gotthelf's Christianity

Reflections .............. 89

WORKS CONSULTED . . . . . . . . . . . . . . . . . 93 


\section{BACKGROUND}

Jeremias Gotthelf is the pseudonyn of Albert Bitzius, a prolific Swiss writer. Born the son of a minister of Murten and citizen of Bern in 1797, he Erew up in the canton Eern and experienced the revolutionary period of the Helvotif and its results. ${ }^{1}$ of this exposure, Gotthelf in ar autobiography writes. "Als wilder Junge durchlebte ich dort die wilde Zeit der Revolution und helvetik." ${ }^{2}$ Describing himself as a wild boy living in a wild time, he is also, according to his own perception, a product of the time he was born in. His formative years gave him a sense for the instability and insecurity of the period. After a period of school and home study, Gotthelf degan his formal studies at the sern Gymnasium in 1812. Upon completion of two years at the Gymnasium, there followed studies in ancient languages, mathematics, and philosophy at the academy which was later taken up into the new Univorsity of Bern in 183/. Three years later, he commenced his study of theology, at the conlusion of which Gotthelf became vicar in his father's parish in 1820. Still feeline a basic restlessness and never having left his native land before, starting the following spring, he spent a year in

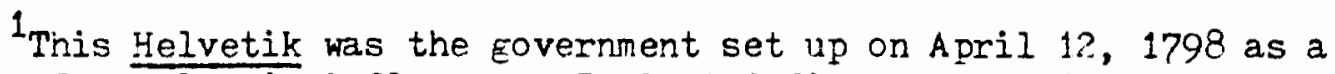
result of Napoleon's influence. It lasted five years and was a failure. For further raading see Feter Durrenmatt, Schweizer GeschichteiZUrich: Schweizer Druck- und Verlagshaus AG, 1953), 382-402.

2 walter Muschg, Jeremias Cotthelfs Fersunlichleit: Erinnerungen von Zeitgenosser (Klosterberg, Basel: Verlag beno sonwebe $\&$ Co., 1944), 
Gottingen, the haven of the Young Hegelians. Aftex his return, he held other assistantships and positions in the church in canton Bern, finally settling in Iltzelfluh, which he felt was in the nost beautiful part of the Emmental. Having been made a minister there in 1832 by the new government, he married and remained in Lbtaelflun for the rest of his Iife. This Emmental and its people, whom Cotthelf grew to love, became the focus of his work as a minister but also the focus and setting of most of his writings. 3

Not only did Gotthelf hold the office of minister; he viewed it as the most important function of his life. He felt he was a minister first and a writer second, viewing his writing as an extension of his function as a pastor. Gotthelf was very productive as a writer. Hunziger and Bloesch have edited Gotthelf's works in 24 volumes and have added numerous supplementary volumes since. 4 (One speaks of three meters Goethe and two meters Schiller; it would not be inconceivable to add a couple of meters Gottinelf in the quantitative sense.) Starting in 1841, with UIi der Knecht, Gotthelf also became a very popular writer throughout many of the German speaking lands. 5 His house was cortinually

Muschg, Persunlichkeit, pp.23-6; $33-4$ contains an autobiographical sketch.

4 Jeremias Gotthelf, Sumtliche Werke in 24 Banden, ed. Rudolf Hunziger and Hans Boesch, Erlenbach-ZUrich: Eugen Rentsch Verlag, 1921). See also Herbert Morgan Waidson, Jeremias Gotthelf: An Introduction to the Swiss Novelist (Oxford: Blackwell, 1953; rpt. Westport: Greenwood Fress Fublishers, 1978), 218-22 for a list of Gotthelf's works based on Werner Gunther, Der ewige Gotthelf.

5 Friedrich Sengle, "Albert Bitzius, pseud. Jeremias Gotthelf (1797-1854)," in Biedermeierzeit: deutsche Literatur in Spannungsfeld zwischen Restauration und Revolution 1815-1848(Stuttgart: J.B. Metzler, 1980), 3:895 writes, "...Auerbach und Cotthelf erreichten die Spitze der damals mbglichen Verkaufsziffern." 
full of guests. This popularity waned toward his death in 1854, as his works became increasingly didactic and political, returning to what characterized his early writings. He considered his writings a tool to help educate people toward a better Christian Iife. In his own perception, his work was a pedagogical effort. This is evident in his letters. 6

In order to understand the education Gotthelf wanted to impart to his readers better, it is extrenely important to note that his faith was protestant in character. To ask what type of Protestant he was could be a topic all of its own. There are aspects of Gotthelf's theology which could be argued to show a nearness to Luther, Calvin, Zwingli, or innumerable others who influenced the faith of the Bernese people. However, Gotthelf did not adhere to any one reformer's particular teachings. Guggisberg writes, "Die Reformatoren sind inm lieb mehr wegen ihres begeisterungsfuhigen Lebens als wegen ihrer Lehre."7 Hans Bayer identifies Gotthelf's theological sources as those of the Laienfrymigkeit tradition, dating back to the Waldensians, the Baptists, the Bohemian Brothers, and the Radical Pietists, the latter taking a critical position toward the Amtskirche. 8 Gotthelf's theology cannot easily be defined. 9 In short, to become a minister in canton Bern,

6otthelf, Samtliche Werke, 390. One particular letter is to Reithart as cited by Hunziger and Bloesch.

7 Kurt Guggisberg, Jeremias Gotthelf: Christentum und Leben (zurich und Leipzig: Max Niehaus Verlag, 1939), 253.

8 Hans Bayer, "Theologische Quellen und epische Gestaltung: Gotthelfs 'idealer Pietismus' " in Deutsche Viertel jahrschrift fur Iiteraturwissenschaft und Geistesgeschichte, 54 (1980), 423-63.

${ }^{9}$ Kurt Guggisberg, a Swiss theologian, was the first to start 
one did not have to be strictly a Lutheran, a Calvinist, or a Zwinglian, but instead had to be in good graces $\mathrm{kith}$ the decision-making members of the Amtskirche whose opinions prevailed. Gotthelf was in any case a devout man. 10

This devotion, however, was questioned by some critics. In spite of his stated intentions - he even saw himself as somewhat of a mystic Gotthelf was attacked by some critics as being too worldly. Although there may have been other misunderstandings, this particular criticism is especially interesting in light of Gotthelf's perception of himself as a devout man. Gotthelf was aware of this critical viewpoint. In the foreword to Uli der phachter (1848) Gotthelf writes: "Der erste Teil war den einen zu weltlich;..."11 "Der erste Teil" refers to Uli der Knecht, the work which is the focus of this thesis. This idea of worldliness was not a contrived concerm on Gotthelf's part; there was actual criticism to that effect. Farticularly the more pietistic elements of Christianity, whose basic view of life is that it is a necessary, temporary evil to be endured, criticized Gotthelf's Lebensbejahung. Sengle writes:

researching Gotthelf's actual theology. He addresses the above mentioned issue: "Gotthelfs Geisteswelt kann unmbglich von einzelnen Einflussspharen aus - etwa von Mythologie, Idealismus und Biblizismus - ganz verstanden werden...Deshalb passt die Religion Gotthelfs auch nirgends ganz in den Rahmen einer Geistesbewegung seiner Zeit oder der Vergangenheit hinein." See Guggisberg, Christentum und Leben. 54.

10."..., und die Ehrfurcht vor diesen wundern veranlasst ihn, sich einen 'Mystiker' in 'gewisser Beziehung' zu nennen." Ibid., 97.

11 Jeremias Gotthelf, Uli dex Puchter(Zurich: Buchergilde Gutenberg, n.d.), 427. In this foreword Gotthelf never agrees that it was worlaly but simply says he never claims to have "hit the mark" but to have strived after it. 
Uli der Knecht wax lange zeit Gottrelfs berintester Roman, hat aber sogleich von pietistisch-christicher Seite scharfe rritik erfarren, was verstundich ist. Der Dichter versucht daher in anderen Romanen die allzu dichte, 'alttestamentarische' Syrthese von Gott und velt, Frommigkeit und Reichtum aufzulcokern. 12

It was not only trese Pietist-Christian critics, I believe, who, because of some undeniable 0ld Testament aspects, misunderstood Gotthelf's intention. Sengle himself seems to agree with those who criticized Gotthelî, as is evident from the above quote. Even such a prominent literary figure as Gottfried Kellex says of Cotthelf's U1i der Knecht: "Diese Geschichte schmeclit mehr nach dem judentur als nach dem Cnristentur." 13 resilizing that such a quote could be explosive, I wish to qualify its detonator by relegating it to the religious sphere for which Keller intended it. He interprets Uli as Jewish in the sense of the God of thunder and lightning, the jealous God of the old Testament. 14 From the above criticism a real problem becomes evident. Here is a minister who considers himself a functionary of God, who views his writings as a tool in helping people to lead a more Christian life, being attacked as too worldly and unchristian. How did such a misunderstanding take place between the author's intention and his actual reception? Ir part this is explained by Gotthelf's realistic style of writing, not to be confused with "worldly", which from the word Reichtum in the above quote, has a definite materialistic focus. Realistic not

\section{Sengle, Biedermeierzeit, 3:914.}

13 Gottfried rieller, "Jeremias Gotthelf," in Samtliche Werke und

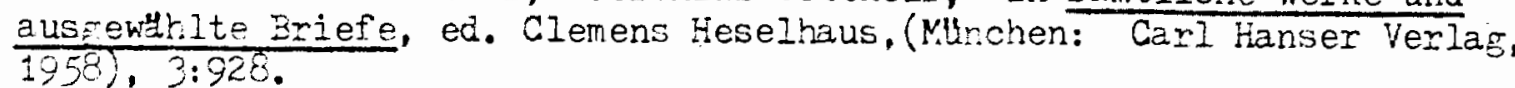
14 Ibid., 3:928. 
in the sense that he belongs to the school of realism, but when writing about his Emmental Beuern, he did not romanticize the Baidernleben like Auerbach. Keller writes: "Er vermag vielleicht noch tiefer herabzusteigen in die Technik und die Taktik des Bauernlebens, gibt dasselbe mit der gryssten Treue wieder... unò scheint chne Nachdeniken und Müssigung zu arbeiten;..."15 Gotthelf's was not a glossed over, purely idealistic or romantic view of life. ${ }^{16}$ The realistic elements also led scholars like Bartels to mistakenly call Gotthelf the "father of naturalism." Eartels along with Muschg, a proponent of the psychoanalytical nethod of literary criticism, helped to contribute to this notion of unchristian worlàliness. 17

My intention is not to supplant the psychoanalytical insights Muschg gives us of Gotthelf, nor to blindly deny the realistic elements of Gotthelf's writing. I do wish, however, to examine an area which can add, I believe, another perspective to this issue of worldiness.

This criticism, i.e. of worldliness, is centered directly on Uli der Knecht, the work which brought Gotthelf onto center stage of the literary world. It took Gotthelf about three months, (August 1840 -

15 Ibid., 3:921.

16 For further information about Gotthelf's "realism" see Werner Gunther, Neue Gotthelf - Studien(Bern: Francke Verlag, 1958), 65-73. Gunther also cites bartels who comments on the realistic aspects of Gotthelf's writings.

17 See Walter Muschg, Gotthelf: Die Geheimnisse des Erzuhlers (Munchen: Verlag C.H. Beck, 1967), 403. For example, Muschg quotes Gotthelf: "Man wird erst recht miteinander eufrieden, wenn man miteinander isst und trinkt." Muschg also quotes Keller from the latter's first criticism, "...es grlunde sich bei Gotthelf alles auf 'eine tiefe Kenntnis des Bauers und dessen, was inm mangelt, auf seine materiellen Interessen'." 
Novenber 1840 ), to write this novel. which was initially intended to be no nore than a "Lektur fur Knechte und Magde... aus ihrem Lebenskreis." 18 Gotthelf states his intent in the full title of the work: Wie Uli der Knecht Elucklich wird: Eine Gabe fur Dienstboten und Meisterleute. It is clear that Cotthelf wrote with a definite goal in mind, a pedagogical one. I believe, contrary to those who accuse this novel of being too worldly, that it in fact is misunderstood by these critics. I am convinced it is intended as a model of how one ought to live, and yet keeps its artistic quality by not simply being a lengthy sermon. 19

The secondary literature on Uli has not yet totally laid to rest the notion that $\underline{\mathrm{Ui}}$ is worldly. In fact, the secondary literature on this novel is relatively scanty. Most of the Gotthelf scholars concern themselves with his writings as a whole. Gottfried Keller, Walter Muschg, and Werner Hahl are examples of those who deal directly with U1i. Others such as Maybaum, Fehr, Bayer, and Gunther write mostly about $\underline{U} \mathrm{Ii}$ as part of a broader topic or area of study. One aspect of Uli has not yet been thoroughly explored, and that is the role of the virtues within the work. They have been mentioned and acknowledged to be present and play a definitely positive role, but so far, as is evident from the quotations, they have been seen as positive in a materialistic sense. A Christian minister - who in this case also happens to be a writer - in whose value system and works virtues would

18 For a more detailed account of the history of the text and its editions see Gotthelf, sumtliche Werke, 4:390-7.

${ }^{19}$ Cotthelf had a high regard for his fellow Bernese, Heinrich Pestalozzi, who was a great example to him. Cotthelf himself was in charge of a school for homelese boys in Trachselwald where he practiced many of the principles laid out in Uli. 
not also play a spiritual role, seems uninginable. Yet, to the best of my knowleage, an interpretation of Uli primarily from the perspective of the virtues has not been attempted.

Certain virtues are recognized in Uli, virtues wich bring a servant to the status of master. Social advancenent as well as materialistic gain are attained through the practice of these virtues. This interpretation alone is inadequate, however, for the lessons in UIi apply to a larger segment of society than just, servant and master. Thus there is also a non-materialistic level to this work which in its relevance transcends time. That non-inaterialistic level becomes accessible through an exploration of the virtues.

We are aware of the seven virtues, the three theological virtues: faith, hope, and charity; and the four cardinal, or platonic virtues: temperance, prudence, fortitude, and justice. For the purpose of clarity, so that the reader and the writer have a common reference point, the virtues of faith, hope, and charity will be referred to as primary virtues. This decision is based on the Pauline epistle to the Corinthians. "And now abideth faith, hope, charity, these three; but the greatest of these is charity." 20 It is due to the Pauline tradition of regarding these three as the more important virtues that I choose to label them primary virtues. In addition to the four cardinal virtues there are, however, other virtues which are considered not only positive from a societal perspective, but imperative in the life of a Christian. Examples of these virtues are: loyalty, honesty, patience, obedience,

20, Cor. xiiv. 13 of the Kine James version. 
gratitude, humility, and others too numerous to list. These are the virtues that will be the special focus in tris reading of Uli. All the virtues that are not primary virtues will be referred to as secondary virtues, including the four carcinal virtues. There is some precedence for this since the cardinal virtues are so called "...because other moral virtues, such as purity and patience, are "derived' from them." 21 I propose that there are also definite reasons why Gotthelf used these virtues beyond wishine to illustrate the way to gain social advancement and materialistic wealth. First, he saw them all as positive, as essential for a Christian life and eventual union with God. Furthermore, Gottinelf has a well-informed social and political activist. He saw this union with God threatened by a negative interpretation of the secondary virtues from sources such as socialism and radicalism and" felt motivated to reaffirm the sanctifying powers of the secondary virtues by showing us a model Christian patriarchal order. 22 I will show from the text of $\mathrm{UII}$ a perspective not understood by many of its critics: namely, that the secondary virtues serve as a base for guiding a wild, undisciplined servant toward not only the status of master with its attendant material gain, but also toward heaven through a process of sanctification. Gotthelf shows how to lead a Christian life in this world without having to renounce the comforts of life, how to gain salvation without austere piety. The latter would, at least in

\section{JCJ Metford, Dictionary of Christian Lore and Legend(London:} Thames and Kudson, 1983), 256.

22 Joseph Maybaum, Gottesordnune und Zeitseist: Eine Larstellung der Gedarken Jeremias Gotthans uber Recht und Staat(Sonn: H. Jouvier u. Co. Veriag, 1960), 21-33. Nayoum examines Gotthelf's political views. 
part, explain the criticism fron the Pietist-Christians.

Furthermore, I will snow that both secondary and primary virtues are actively present in Uli as examples for all reacers. The secondary virtues exist, as will be evident from the text, to help one lead the Christian life in a concrete, tangible way. The practical application of relifion was of central importance to Gotthelf. He considered the Fietists, having their birth in the Erweckunssbewegung, "zllgellose Schwermerei", and he fought against what he considered their affected piety. $^{23}$ The actual practice of the secondary virtues then leads one to the primary virtues, which in turn bring out the godliness in human beings. The acquisition and practice of these virtues bring not just hope for salvation in the next life, cut also a state of happiness in this one.

The last. two sertences of the above paragraph explain the perspective this thesis will take of Uli. In this interpretation the influence of Calvinism may seemingly become manifest in the work, and yet I do not believe that Gotthelf is arguine that those who have success in this life are the ones whom God favors and are thus assured salvation. Calvinism, with its teachings of predestination, didn't make much sense to Gotthelf, according to Guggisberg. ${ }^{24}$ But, showing Old Testament influence, Gotthelf does argue in Uli that those who are virtuous will be blessed and prosper, while those who are sinful will not. ${ }^{25}$ one can observe how Uli's inner transformation

23 Bayer, Theologische quellen, 426. Further explanations, 426-31. ${ }^{24}$ Guggisberg, Christertum und Leben, 104. 25 This is what Keller sees as Jewish rather than Christian. 
is accompanied by outward, empirical evidence of his spiritual progress. is his faith in his master, himself, and coo increases, so does his materiai condition. This, however, happens only after vil has put certain seconaary virtues to the test and Found that they work. For example, his master tries to teach him thrift. After much strugsling, Uli finds it beneficial and thereby gains faith. The material and the spiritual are intertwined. This is another aspect that, I believe, Kelier observes as Judentum in Uli. Gotthelf makes the importance of this relationship very clear. Maybaum quotes Gotthelf:

Das Leben ist der Einsatz, den ich von Gott erhalten, den Himmel mit ihm zu gewinner. Das Hbchste, was dem Menschen auf Erden zu erringen gegeben ist, ist die Vereinigung ces Himels mit der Erde, ist die Gemeinschaft mit dem Vater aroben.

Then Maybaum explains: "Der Kensch muss danach streben, die ewige Seligkeit im Himnel zu erringen. Das ist der Sinn des ganzen menschlichen Lebens bei Gotthelf immer wieder." 26 "Worldly" then is a false perspective that excludes the real role of the secondary virtues in the eventual salvation of Uli. Keller, in spite of his criticism, had to admit that this was a Christian notion of salvation. He writes: "Fragen wir nun nach dem Erinzip, zu welchem hinauf urd durch welches Gotthelf seinen Uli serettet hat, so finden wir ein strenges, positives Christentum."27 It is Uli's salvation which is at

Gotthelf does see relevance in the Old Testament for Christianity. Guggisberg writes: "Gotthelf liebt das....Alte Testament..." (Ibid., 55.)

$$
\begin{aligned}
& 26 \text { Kaybaum, Gottescrdnuns, 43-4. } \\
& 27 \text { Keller, SEmtliche Wenige. 3:927. }
\end{aligned}
$$


stake; those same virtues which lead to material well-being also lead to an acquisition of the three primary virtues and to ultimate salvation. Naterial gain is seen as a blessing from God; the reward for leading a virtuous Cnristian life is cestowed in this life as well as the next. In Uli, Gotthelf shows us a God who is not aloof from the affairs of mankind, but who is directly and imnediately involved with the hero's salvation. Uli finds his happiness in the process of his being led to

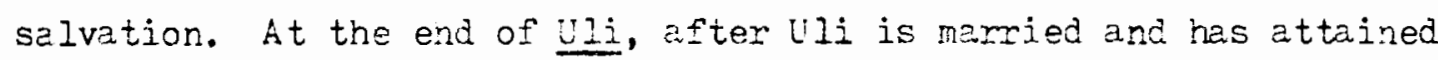
the mastership of the Glungge, the connection between the worldily and the spiritual is made clear:

Und es stunden wiederum die Sterne am Himmel, als nach recht innigem Abschied, wie er selten von Nichtverwandten genommen wird, der mutige Kohli ein Eilickliches Faar rasch davonfuhrte - dem Himmel zu. 28

Happiness in this life and salvation in the next are found through the same means. They are both gained through leadine a virtuous life. To further substantiate this from the text, there is a key quote, which will also be addressed in the second chapter.

Das Weltliche und das rechte Geistliche sind viel naher bei einander als die meisten Leute slauben. Sie meinen, un recht wohl zu sein auf der Welt, mlisse man das Christentum an den Nagel halngen; und das ist gerade das Gegenteil. 29

The virtues then become, as a model in Uli, the means of leading everyone to both happiness in this life and salvation in the next. This novel is meant to teach us exactly that. "Merke dix das, lieber Leser! ${ }^{30}$

28 Gotthelf, Sumtliche Werie, $4: 387$.

29 Ibid., 4:375.

30 These are Gotthelf's last words in Uli, Ibid., 4:387. 
CHATER II

THE TEXT

This chapter will be an attempt to prove the thesis directly from the text. The character development of Uli is central to this proof. The development takes place chronologically from the beginning of the novel. This transition is the focus of the book. It is, after all, a stcry of "wie Uli der Knecht Ellkrlich wind." Since it is Uli's development and actuel. process toward happiness and salvation that is beine traced, it is necessary to follow the text sequentially rather than topically, i.e. examining different aspects of the novel separately. The latter will be done in a subsequent chater.

The nature of Uli's development also does not allow us to construct a mathematical flow chart which would list all the secondary virtues next to all the primary virtues each one could lead to. The development is rather spiral, with many of the virtues interrelated. Wach time Uli exercises faith, he makes some progress, but it takes that much more faith to go on with his next stage of development. He exercises more secondary virtues because his faith has increased. In turn, his faith has increased because he sees that the practice of the secondary virtues was rewarded.

By following the text from beginning to end, it will become evident why Cotthelf did not let Uli find hapeiness. Rather, Uli becomes happy. This becoming impiies effort, hard work, having nothing 
to do with Iuck. Uli, havine practically no faith at all in the beginning, later develops faith and love through the practice of the secondary virtues. The faith and love he develops bring him not only the beautiful Vreneli, but also a strone, positive relationship with God̀.

The story begins when Johannes, the Eodenbauer, arises at 4: 30 a.m. to do the feeding, because his farmhand, Uli, "ist erst nach der. zweien heimgerommen urd noch die Steige herabefallen, als ex ins Gaden wollte." 31 we are introduced to an UIi who is wasteful, drinks too nuch, and spends time with a girl of loose roral character. Eisi, Johannes' wife, encourages Johannes to talk with UIi in the Stubli, which he fully intends to do. 32

Gotthelf then digresses into an explanation of the farmer aristocracy, of which Johannes is a part. In doing so, he reveals the character of Johannes. The reprimand Uli receives is given in a fatherly way, making sure that justice prevails. "Von der Selbstbeherrschune und ruhigen Gemessenheit in solchen Husern vermag man sich kaum eine Vorstellung zu machen." 33 These three secondary virtues: justice, self-control, and temperance exexcised by Johannes, set the atmosphere for the talk with Uli.

\section{${ }^{31}$ Cotthelf, Stmtliche Werke, 4:7.}

32 Accordine to Neuenschwander, there are certain places in the literature of Gotthelf where confidentiality, trust and fäith can be built. The stubli is one of those places, a room which by the very sound of its name conveys a feeling of warmth and security. See Martin Neuenschwarder, Jeremias Gotthelf als Dichter der Ordnung (Zurich: Juris Verlag,, 1956$), 123$.

${ }^{33}$ Gotthelf, Sumtliche verke, Li:9. 
Johannes' talk with Uli remains without success. Uli's head is still not clear from his drinking of the night before, and he is rebellious. Johannes, on the other hand, remains calm and composed. After Uli's head clears up, his conscience starts to bother him.

Here we clearly see that the seed for Uli's progress is planted through a role model of virtuous behavior. His master creates an environment in which UIi becomes acutely aware of his moral inferiority and therefore his conscience starts to bothen him. This is especially the case in his premarital relations with snne Iisi. His master makes it clear to him that the resporsibility for an eventual presnancy could fall on him just as well as any of the others she is having relations with.

Gotthelf now explains to the reader that passion and love are not necessarily synonymous. In fact, Uli was not capable of real love at this stage of his life. "Nem es vielleicht auffallen mag, dass Uli solche Angst vor Anne Lisi hatte, dass seine Liebe zu demselben so schnell vergangen schien, dem muss ich bemerken, dass UIi gar keine Liebe hatte." 34

Uli, the antithesis of Johannes, is now being prepared for Johannes' influence. An internal effect begins with an appeal to the individual's conscience, an internal system of measuring right and wrong. ive need to note here, however, that Uli's repulsion of cinne

34 Gotthelf continues: "Er gehbrte unter die vielen, vielen Bursche, welche aus Grosstuerei die leidige Sitte des Kiltganges treiben so frllh mbglich; ....Bei ihnen wird nie Liebe sichtbar, sobald ein Madchen sie anklagt; ..." Ibid., 14. The Ki ltgang is the nocturnal visit to a girl by a young man. Cotthelf spoke strongly against this practice. 
Lisi is still. a selr-centered one. His motivation is not to bear the fiscal and legal resconsibility of a pregnancy which would be an insurmountable burdel to him this stage of nis life. It, in fact, would mean his ruination.

Johannes' motivation lies therein, that he wants to help Uii get closer to God, and he does this out of his own love of God and his neighbors, accordine to Christian tradition the two greatest commandments. This point is brought out by the following cuote conceming Johannes:

iber wenn en des Vli redachte, und wie der. Iiebe Gott inn so furstlich ausrestattet mit Gesundheit unc kraft, und vie Ui seines Schypfers so ranz versesse, so schnbde seine Gaben misbrauche, so wurde er ganz wehmlutig und stuno oft und lange still, sinnend, was er inm woh $\frac{1}{3}$ sagen sollte, dass er wieder werde ein Freis seines sch pfers. 35

Whatever methods he applies, their ultimate goal is to lead UIi to a positive relationship with God. If this is kept in mind - that all the carrots being later dangled in front of Uli are motivational devices leading to this goal - then the pietistic clains of worldliness in the work become very questionable. It would seem rather that these Pietists, as well as anyone else who criticized this work as being too worldly, either didn't understand or rejected Gotthelf's notion of the relationship between the temporal and the spiritual. Gotthelf is also very realistic in showing that it generally takes more than mere semons to convert a totally world-oriented, ungodly individual. There have to be methods. These methods are, in this case, the secondary virtues which can bring one to a condition of respect and well-being. The 
ungodly sees no further than the material reward for his application of the secondary virtues, but the true Christian krows that it is not the only reward. These virtues do not only lead to worldly success but also to God. "Las rechte weltiche Gluck und das himnilische Gillck werden akkurat auf dem gleichen wege gefunden." 36

To further establish Johannes' role as a type of priest for his entire housenold, and especially for Vli, Gotthelf puts the following words in his mouth:

Und er wolle ihnen geradeaus sagen, dass kein Keister einem Dienst trauen kBnre, der Gott aus dem Sinn geschlagen habe und lott untreu geworder sei, ob man dann erwarten k8nne, dass ex Menschen treu sein werde?" 3 ?

Two aspects are born out by this quote. First, the secondary virtues of trust and loyalty are introduced, the latter is of central importance as it establishes the positive relationships in Uli's future that allow him to exercise some of the other virtues. 38 The second aspect is the assumption that a relationship with God is more valued than one with fellow human beings. Therefore, if one does not have or breaks a relationship with God, how can that person be trusted in his

$$
36 \text { Ibid., } 381 .
$$

37 Ibid., 17. Karl Fehr explains this role in these terms: "Die Familie ist nicht nur eine biologische oder soziale Organisation, sondern ein religibses Phunomen." Karl Fehr, Das Bild des Menschen bei Jeremias Gotthelf(Frauenfeld: Verlaz Huber \& Co. A.G., 1953), 265. Wíabaum enlightens us further: "In einem christlichen Hause dagegen ist der Vater der Friester und das Haus sein hltar." See Maybaum, Gottesordnung, 78.

38 Gotthelf's own analysis of yli credited this virtue as the central virtue of the work. In the foreword to Uli der fychter he writes: "Der erste Teil dieses Buches enthielt die Geschichte eines Knechtes, welcher durch Treue aus einem knechte zum Meister wurde." See Gotthelf, Fuchter, 427. 
or her relationship with other peopie? This seems to be an axiomatic twist to an aphorism well-known to the Chxistian world: "Denn wer seinen Sruder nicht liebt, den er sieht, wie kann er Cott lieben, den er nicht sieht?" 39 Gotthelf here seems to stand that zrgunent on its head and say, if one is not loyal to God whom one hasn't seen, row can one be loya I to a brother whom one has seer.

This loyalty between a person and Cod is what Johannes would like his entire household to have. It is obvious, however, that Uli is not ever close to that iceal. It is this process of getting there that makes up the storyline of this novel.

While Johanres and uli wait for a cow to give birth to a calf, an opportunity presents itself to speak privateiy. UIi expresses his conviction that he will never amount to anything in tisis world and that one will not allow him to experience the only joys he can afford in life. Uli feels that smoking, drinking, and the kiltgang are the only pleasurable aspects of life he will ever be allowed to experience. Johannes is quick to explain to him the erxors of his perception of those experiences as joyful.

Aber, UIi, was ist das flir eine Freude, wenn man darauf eine ganze Woche nirgends sein darf, es einem nirgends wohl ist? Was ist das flur eine Freude, die einem fur das Eanze Leben elend und unEl'lcklich machen kann? Solche Freuden sind des Teufels iockvtgel. 40

Johannes makes allowances for joy and pleasure in life, but admonishes Uli to find joy in trings which are good and allowed. Johannes is not teaching austerity or feigned piety, but temperance and self-control,

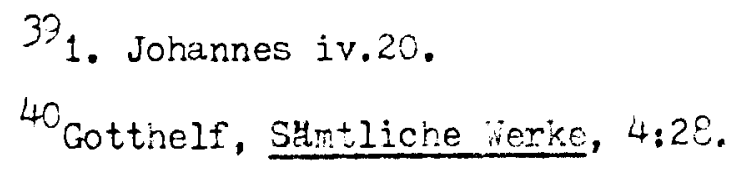


virtues which he already possesses.

He wants to awaker the fath in Ui. Since Uli does not as yet have a trust relationship with God, his master will serve as God's proxy, or better said, his priest. Uli, seeine that the way he has lived so far has not gotten him anywhere in life, has corcluded that he'll never amount to anything. He is now asked to exercise a primary virtue, faith, in his master. Johannes tells him his situation is not as bad as he thinks, "Wenn du es nur glauben wolltest." ${ }^{41}$ Furthermore, he tells him to change his lifestyle so he can become a man. He tries to motivate him by telling him that there have been many who haven't had more than Uli and row have "Haus und Hof und Stlll und har." 42 Faith is what eventually brought these people to success, but being a primary virtue, it is precisely what Uli is still lacking. His master's telling Uli that the latter's primary problem is a lack of faith and were he to change his belief the outcome would also be different, is still too abstract for Uli. Uli insists on the element of luck in the success stories of Johannes. Johannes, in turn, becomes resolute to help Uli achieve the virtue of faith. This is progressively achieved through the secondary virtues.

Uli insists he earns too little, needs too many clothes, and has debts. His conclusion is that in such a situation saving will amount to nothing. Johannes now recalls what he has learned from a minister that will be helpful in changing Uli's attitude. It is significant that Gotthelf puts the advice for conquering life in the words of a

$$
\begin{aligned}
& 41 \text { Ibid., } 29 . \\
& 42 \text { Ibid., } 29 .
\end{aligned}
$$


minister. The certral theme is still loyalty and serves to enlighten us as to the role of this secondary virtue. The master, paraphrasing the minister of his youth reiays the following:

Alle Menschen empfingen von Gott zwei grosse kapitale, die man zirsbar zu machen habe, namlich Krafte und Zeit. Durch Eute Anwendung ${ }_{4}$ derselben millsten wir das zeitliche und ewige Leben Eewinnen.

Uli now hears an explanation that many have nothing on which to exert their strength or with which to occupy their time groductively. These people then lend their strength and time to those who have too much work but not enough strength and time. They do this for payment and that is the meaning of serving. Most servants, however, regard this serving as an unfortunate situation and perceive their master as an enemy and suppresscr. These servants then deem it an advantage to do as little as possible and waste as much time as possible. Thereby they become disloyal, because they are keeping from the master that which he bought, namely their time. This disloyalty brings its own punishment. When one is disloyal toward a master, one is also disloyal toward oneself. Habits and attitudes are formed which keep such a person from makine any progress and amounting to anything.

From this explanation we can see that Gotthelf's world is not compartmentalized into economics, family life, and religion. They are integral parts of life. Here again the linking of Earth with Heaven can be observed. Earthly and eternal life are won the same way, by the application of time and strength. In other words, what one does with the capital God has endowed makes the difference between 
success and failure. Loyalty is central to this application because loyalty deternines the actions and attitude of the servant. It develops a pattern of behavior which car bring success both in the temporal and the spiritual realn. If one is disioyal, on if trarsferred into the primary virtue level, unfaithful, the consequences stay with such a person "bis vor Gottes Richterstuhl." 44 These habits don"t only determine our temporal existence but also our potential salvation, accordinE to Gotthelf.

The virtues wich make someone into a good Christian are the same ones that bring us success and rightful recognition, $i . e$. respect in the world. Such a synthesis of Earth and Heaven, althourh widely recognized by critics, is still cause of much confusion. 45 Yet this is exactly what Johannes is trying to teach Uli.

What the master says, i.e. words alone, do not make enough of an 44 Ioid., 31.

45 Maybaum writes: "Auch wendet er sich schars gegen Sensualismus und Diesseitsfreude...Gotthelfs Weltanschaung bleibt aber fest in Jenseits verhaftet...." See Maybaum, Gottesordnung, 26. Yet Fehr sees a break with a Jenseitsorientiemung starting with Uli. Iookine at the factor of antimaterialism he writes: "So hebt Gotthelf mit dem liliRoman den Eindruck eines einseitingen Antimaterialismus... auf," (see Fehr, Das 2i1d, 256.) It is interestine that whether it is ar issue of materialism, piety, or any number of other items, there usually seem to be two divergent perceptions of where Gotthelf stood. Somehow a synthesis seems to be difficult to accept. One has to believe in either evolution or creationism; one is either materialistic or antimaterialistic. For this work such a black and white perspective is inadequate. This can be seen in the various labels attached to Gatthelf. He's been called a naturalist, a realist, a proponent of Heimatdichtung, of Dorfliteratur, and yet romantic aspects are found in his writings. Timewise, Gotthelf belongs to the Biedermeierzeit, but quite frankly, many scholars don't know where he fits. It is the same with the topics of his writing. Wuch of the confusion comes from trying to find a single label for Gotthelf. 
impact on Uli. He is given an ultimatum to change or find another job. After this talk, both of them assume that Uli is staying without another exchange of words. Uli thinks about his master's words, but not until confronted with the possible reality of potential outcomes of his past actions do they make a strong impact.

Anne Iisi appears out in the field where UIi is working. "Wie vor einer Schlange gebissen fuhr Uli auf... Er gedachte seiner moglichen Vaterschaft und... hatte ein bbses Gewissen gegen inns." 46 Uli is still totally in the worldiy realm and sees the potential consequences from this perspective. He is very uncomfortable now and breaks off his relationship, thereby gaining additional secondary virtues. He becomes chaste and undergoes a moral purification, and even though his behavior is secularly motivated this has positive spiritual consequences. From here on Uli engages in no more premarital sexual relations. Although the impetus to change came out of fear of a pregnancy that would be ruinous for Uli, the acquired virtues of self-control and chastity will later be continualiy supported by other virtues. The original warning of Johannes has now assumed a degree of reality in Uli's mind and forms a base for a small amount of trust on which Uli can later build some faith in his master, thus setting the stage for his spiritual frogress.

Now that UII has become chaste, he starts to think about the words of his master regarding loyalty. Thrift now joins the already mentioned virtues. Each secondary virtue can degenerate and become negative by being carried to its extreme; in the case of thrift, the 46 Gothelf, Sumtliche Uerge, 4:37. 
extreme is avarice. Generosity is the balance which Johames uses to show roodwill toward Uli. After a day's work they stop at an ir: and tohannes buys good wine, not the cheapest. Thereby liz becomes conversational, The topic of discussion is Uli's earnings. Uli has never understood how to save money. No matter how he added it up, he needed all his money clus some more. He tells Johannes that his former minister may have inown a lot of things but coulan't have hac any idea what an crdinary farmband earns. His master row shows hir how he can be thrifty. The ten Freuzer which Uli usually spends for pleasure should rot be spent at all. Johannes demards a commitment to a total change. He explains that just cuttine back a little won't do ary good. Soon he rould find himself back in his old habits.

Jann komnt der Nachdurst, und du musst andere $A$ benden nachbessern und verlierst immer mehr allen clauben, dass du dir je aufhelfen konntest, wirst alle Tage liederlicher und verzweifelst immer menr an dir selost. 47

To build faith in oneself or someone else requires action, a total commitment, not a halfhearted trying. Gotthelf's idea of faith is not one of a naive pietistic belief. Faith is made to happen; it is built. Built on what? The secondary virtues. Thrift will result in actual savings. The result shows that the initial little trust was not misplaced and thereby increases one's faith.

Johannes keeps enough distance to allow Uli to make his own decisions, because the action has to originate with the person needing to gain the faith. Fehr also substantiates this. "Denn die Art, wie Johannes seinem knecht gegenlubertritt wird allein von der christlichen 
Asape bestimmt... was da als geistiger Leib geboren werden soli, ist kein Aufzwingen eigenwiliger Gedanken." 48 Although Fenr mentions this in conjunction with the symbolism he sees in the birth of the calf, an earlier instance, ard uli's spiritual rebirth, this is part of Johannes' insight throurhout. He can only be a catalyst for change; Uli has to do the actual chaneing.

If Joharnes also reoresents God, then Jesperson's comments also become very meaningful.

Although God may intervene in the lives of men, he does this only to chastise anc to direct, never to determine. The decision to accept or reject this divine assistance is always, in the final analysis, man's decision. This means in effect that the determining factor in man's salvation is not irresistible divine grace. 49

Free will then plays a very significant role in Uzi's development. Even though Johannes confronts Uli with choices and decisions to make, he is never coercive.

Just like loyalty is connected with faith, Johannes' generosity is linked with the Christian love of onés fellow human being. To teach Uli this idea, Johannes tells the story of a man he met on the road to a market and quotes this man to illustrate the balance between being a spendthrift and greediness.

Du musst nicht glauben, dass ich dabei ein wisster Gythung sei. Es ist schon mancher z'leerem von grossen Bauemhuusern weggegangen und hat bei mir erhalten, was er notig hatte. Ich habe nadisch nicht vergessen, wer mir den Segen zu meiner Arbeit gegeben hat, und wem ich bald Rechnung ablegen muss. 50

48 Fehr, Das Eild, 260.,

${ }^{49}$ Robert Clifford Jesperson, "Jeremias Gotthelf and the Christian Order: a Study of Gotthelf's Social Philosophy as it Relates to his Theology." Diss. Stanford 1966, 60.

50 Gotthelf, S4mt Iiche Werke, 4:42-3. 
This "Abgabe einer Rechrung" has its theological foundztion in that one is accountable to God for all one's worldiy possessions, since they are only given us on Ioan for this Iifetime. Thrift is here used to enable a person to better exercise neighborly love, not as an end in itself, or to gain riches for riches' sake. Again a secondary virtue, thrift, supports a primary virtue, love, leading one closer to God. This is especially the case when considering oneself a steward over things God has entrusted one with for a brief lifetime。

Johannes knows that he has to help Uli increase his faith. He therefore asks Uli to follow his advice. Obedience can now be added as an additional secondery virtue; not unquestioning servility, but a conscious decision to place trust in someone else that they will lead one in a way that is best for oneself. As extra encouragement for obedience there is again a material reward waiting. Johannes tells Uli that if he will believe and obey him, he will be out of debt by the end of the year, and the following year he will have a surplus. Furthermore, Johannes says that if Uli will believe and obey him, there is no reason why he couldn't give Uli a raise in his earnings. "Denk daran Uli: je besser die Gewohnheit, je besser der Name, desto besser auch der Lohn." 51 Although the reward Uli has in mind at this point is strictly material, he will, of course, also gain spiritual rewards in the process. Uli is doubtful about his own ability to be believing and obedient. Consequently, Johannes challenges him to try it for a month.

This seeminely worldly bait, i.e. the promise of better pay and

$$
51 \text { Ibid., } 4: 44 .
$$


freedom from indebtedness, is not only UII's motivation materially but also leads him closer to God.

Und es ging recht ordentlich manchen Sonntas lane. Der Uli ging wieder zKilchen und dachte daran, dass er ein Mensch sei, und dass er auch selig wexden mbchte. Er fing an ziu flauber, dass der Neister doch etwas recht haber. mbcht!; denr wenisstens zwei Neutaler hutte er fruher in dieser Zeit fur nichts ausgegeiden, die er noch im Sack hatte. 52

Uli has empirical proof in his pocket that what his master tells him is true. Yet his faith in his master is still qualified with the word "etwas". The sentence is furthermore in the subjunctive mood, connoting doubt. The srowth in faith is definitely evident, however. His faith in himself increases and with it comes a feeling of self-worth that causes him to think of higher goals than the material, he concerns himself with his possible salvation and starts goine to church again. Through the prospect of worldly success the prospect of spiritual salvation becomes a simultaneous and conrected concern of Uli. Uli wants to be saved, but he needs tangible proof that what his master says is true. For Gotthelf faith is not limited to Christian mysticism. Faith, for him, is a power, or energy, toward sanctification. In matters of faits he doesn't distinguish between worldly and spiritual spheres; they are closely tied together.

As soon as UIi lets the already mentioned virtues operate as positive forces in his life, other people try to interfere and lead him away from his new path. Johannes is not an obtrusive individual; he does not involve himself in other people's business without being asked, yet he is wise and not naive. As a weapon against the attempts 52 Ibid. $44-5$ 
of others to make Uli hostile towara him, he uses the virtue of love. "Es braucht viel kraft und viel klüheit, solche komplotte zu zersturen, urd viel liebe und viel aufrichtige wohlmeinenheit, sie nicht eufkommen zu lassen," says Johannes. 53 It again is the exemplification of the virtues that are to influerce $\mathrm{u} I \mathrm{i}$ in a positive way.

Uli's faith is not yet strong and he begins to listen to those unfriendly forces. While they are influencing him, he becomes dissatisfied and ili-humored. The classic Faustian strucele ensues within his own breast. Eut perhaps a more apt description would be that of the basic human strugele between two different dispositions. on the one siaje is his good master who has proven to UIi that if he would listen to him there would be hope in store. On the other side those who want to sow discord between UIi and his master by trying to convince him that Johannes is only using him, that through Uli's efforts, it is Johannes who is the real beneficiary. Eut Uli has sufficient experience now that he does not immediately succumb to the negative influences. Fis character has acquired a certain defree of indejendent strength at this foint.

Er sah doch, dass auf des Meisters Seite die grossere Gutmeinenheit sei, und dass wenn er diesem gehorche, es ihm besser Eehe, und wenn auch der Neister Nutzen hatte von seiner guten Aufflihrung, so hatte er selbst doch noch den grbssten und bleibenderen davon. 54

This is quite a different disposition than at the beginning of the novel. Uli is now accepting the additional responsibilities he is

$$
\begin{aligned}
& 53 \text { Ibic., 4:46. } \\
& 54 \text { Ibid., 4:46. }
\end{aligned}
$$


ertrusted with as ar opporturity for his own benefit. He is able now to see hope for tine future. What else could be meant bej "bleibenderen Tutzen" tian qualjties and experiences to be used sometime in the sutuce. If che articipates schething being useful in the future, there is an implicit expectition of a positive experience, a conquering, an overcoming of some challenge. Uli is now strongly considering such a positive future, and $i t$ would not at all be amiss to assert that at this point Uli is acquirir. the rrimary virtue of hope. Ey now vij has a.Iready undergone a ereat change.

ris faith is not yet compiete, however, and as cotthelf writes: "Is kam inm vor, als ob zwei Mechte sich um seine Seele stritten, fast EIeichsam ein guter und ein buser Engel, und jeder ihn haber wollte." 55 This struEnle cortinues on through still many events.

Uli is not jet convinced of his master's propitiousness and allows himself to be talked into a jurnussspiel by old friends. Johannes counsels against it but $\mathrm{Uli}^{\prime} s$ old friends lead him to believe that his master warts to keep him at home to get more work out of him. Uli plays. His team looses and has to pay the bill at the tavern for the other town's team. A fight breaks out and Uli's clothes get destroyed. Because of that and the big bill at the tavern, he feels that frugality was not worth the trouble. "Er hatte allen Mut verloren,..." $\mathrm{vli}$, who had up to this point practiced the virtue of frugality now misunderstands why it doesn't work for him. His faith is still linked to empirical proof. The others who took part in the fight now want

$$
\begin{aligned}
& { }^{55} \text { Ibid., 4:46. } \\
& { }^{56} \text { Ibid., 4:63. }
\end{aligned}
$$


to make Uli solely responsible for that fight by taking advantage of his illiteracy and making hin sign a statement, blamine him for all the damages and in effect financially destroying him. uli does not believe that people could possibly be so bac. Johannes, although somewhat angry and indignant, continues his goodwill toward Uli; he remains the example of positive virtues. What foliows is an "I told you so" lecture, in which UIi receives the exhortation to be obedient and have faith in jchannes. However, Uli only believes later when he discovers the actual content of the letter.

Uli is now ready to promise loyalty to his master in return Ior which Johannes helps him out of his predicament. Just as God can only help and influence those who accept him, so Johannes exposes Uli to the virtues of faith, Iovalty, and goodwill by making his help theoretically conditional, knowing full well that Uli had nowhere else to turn to for help. This is expressed in the following quotation:

'Das kUmmt darauf an,' sagte der Neister; 'wenn du mir diesmal glauben wilist, dich nicht willst misstreu machen, aufreisen lassen, so verspreche ich, dir hinauszuhelfen. Willst du aber den anderen wiederum mehr giauben als mir, so kannst du meinethalo; siehe dann, wie es dir geht! Ich habe es dir im voraus gesagt, wie das Ding auslaufen werde; aber du hattest zu den anderen mehr Giauben als zu $\operatorname{mir} .57$

Johannes sets up a situation in which UIi has to make a total commitment. This he does and Johannes functions as an intermediary for Uli, who finally acknowledges his error and increases his faith in his master. The level of faith which Uli reaches is attained through Johannes' patience and goodwill. He is the catalyst who, with the use of the secondary virtues leads Vili to the primary virtues.

$$
\text { 57Ibid., 4:68. }
$$


Uli now bettors himself procressiveiy. He utilizes the secondary virtues, especially frugality, to his benefit. He begins to read, specifically the Bible and the calendar, the two literary staples of the Emmentaler famer. Johannes allows Uli to visit the Stube, the sanctuary of the farmhouse, and becomes more and more a father figure, not only spiritually, but also temporally. He teaches him about agriculture and everything attendant to it and gives Uli increasingly more responsibility. Uli does not feel taken advantage of but perceives it as an apprenticeship and recognizes elements of his own character cevelopment.

Through UIi's now virtuous living, he is continuelly brought closer to God by a Christian master. Uli's change also has its effect on the other servants. They all start to have an "appetite" for the word of God and like to hear the sermons. Bible study becomes an integral part of their activities, including discussions at table, perhaos following luther's model. If someone feels the urge to mock, he is quickly reprimarded by the others.

Sie wurden dabei sich immer mehr bewusst, dass es doch etwas Hohes und Bedeutendes sei, ein Christ zu sein, und dass ein christlicher Knecht doch viel besser daran sei als ein heidnischer K४nig, der nicht recht wisse, warum er auf der Welt sei, whhrend der christliche Knecht doch wisse, dass ex da sei, um ein Kind Gottes zu werden und das Himmelreich erblich zu erweben. 58

In this way Gotthelf now describes not just Uli, but all of Johannes' servants on whom Uli now has a positive effect. Uli, through his virtuous behavior, now becomes a Christian and steps on the path toward salvation.

$$
58 \text { Ibid., 4:81. }
$$


Uli becomes loyal, thankful, thrifty, industrious, and humble, all secondary virtues. Everything goes well with Uli and, "Er hatte nie geglaubt, dass das Geld so darhalten k8nne;..."59 Uli's humility and gratitude is also evident in his change of attitude toward his salary. Whereas before he complained about not making enoush money, now it seems to him he doesn't earn what he gets. "Uli meinte, der Meister hatte ihm schon zuviel gegeben, und alles durfte er nicht nehmen, er hatte es nicht verdient." 60 Uli has acquired many secondary virtues which are of great benefit to his progress. As he practices them he gains an immediate reward which reenforces his faith that he has placed in their efficacy.

Yet Uli still makes mistakes. His trust in his master is not yet complete. He wants to increase his monetary worth and lends out his money against the wise counsel of johannes. He is impatient and seeks to become rich immediately now that he has experienced some success. Naturally, he doesn't see any of his loaned money again, excepting a small portion which his master collects for him after Uli pleads with him to do so. Uli now makes his acquaintance with the secondary virtue of patience. He has seen some of the fruits of his labor and is now impatient, anxious to get on in life. Still having to learn the proper balance, Johannes counsels him. "...diese Ungeduld ists, was so viele Menschen um $\mathrm{Hab}$ und Gut bringt... Warte nur einige Jahre, lege immer zu, so wirst du sehen, $z u$ welchem Kapital du kommen wirst." 61 The secondary

$$
\begin{aligned}
& 59 \text { Ibid., 4:85. } \\
& 60 \text { Ibid., 4:85. } \\
& 61_{\text {Ibid., } 4: 91 .}
\end{aligned}
$$


virtues in and of themselves, if carried to their extreme, can turn negative. To keep thrift from becoming avarice and greediness, patience is required as a balencing factor. Gotthele's realism again comes through in the recognition that it will take years for Uli to achieve his Eoal. This is not one of those Horatio Aleer stories in which an unrealistically good protagonist fights against the odds and "chance, or let us say Providence, brought him a liberal patroness." 62 Nor is there any of Alger's melodrama, overnight rags to riches, superficial characters or statements such as: "He looks honest." 63 Gotthelf does not write unrealistically moralisine stories such as ilger will be doing later in America. He coesn't give the reader any false notions of getting rich quickly. It is a long, arduous process durine which many virtues have to be acquired. That in and of itself also attests to the spiritual level of the novel. It is not the end of getting rich that is the focus of Uli; it is the process through which Uli is transformed that makes the novel what it is; namely, a peciagogical effort on the part of Gotthelf.

Further evidence of a link between the worldly, i.e. temporal, and the spiritual is found after Uli has a negative experience in lendinE out his money. In response to Johannes' advice, Cotthelf narrates: "Und Uli tat so. Er blieb sparsam, ward immer anschlagiger und emsiger und wuchs zugleich an Weisneit und Verstand und an Cnade

62 Horatio Alger Jr., The Train Boy (Leyden: Aeonian Fress, Inc., 1975), 67.

$$
63 \text { Ibid., } 97 .
$$


bei Gott und der Menschen." 64 This is an obvious refererce to a Eible passage. These very words were used in describins Christ. 65 It becomes evident that Gotthelf did not use these words by chance. They are written with a definite intention. Based uron the transformation we have seen so far, it is safe to propose that Uli is here portrayed as a true follower of Christ. The same words that were written to describe Christ in his youth is now written to describe UIi in his spiritual youth, underscoring UIi's growing relationship to a Christian God.

What we are seeiner is the inner spiritual development of Uli. But how does one measure spirituality? Ey the amount of prayers one says? Ey the amount of alms given? What is evidence of spirituality? How can one teach soneone as tied to the earth as an Emmentaler farmer how to gain spirituality? It cannot be done by abstract ideas. It cannot be done. by metaphor or allegory, not by a negation of the concrete world of the farmer. His dependency on the God of nature necessarily ties his temporal world to his spirituality. For Gotthelf it is the virtuous life which shows spirituality. Because secondary virtues are seen as positive, their product is also positive. This product is both physical well-being and a growth in spirituality. In fact, if the former and the latter come through the same application of the same virtues, they are necessarily dependent on each other. The material progress becomes a manifestation of the inner spiritual progress. Consequently, material progress becomes the measuring tool of spiritual progress.

64 Gotthels, Sumtliche Werke, 4:91-2. 55 iuke ii. 52. 
Gotthelf now describes Uil as a man whose outward appearance reflects this inner change. It is now thit Uid stands exect like a real humar being, writes Gotthelf. Fe further coments that UIi is often mistaken for a farmer's son and not perceived as a servant. This is not due simply to the clcthes and the silver watchchain he is wearing but also his demeanor and his civil behavior. L'li's perspective changes as he gains possessions. He begins to feel a peaceful security which comes from higher self-esteem and a growth toward finarcial independence. Gotthelf again shows us the balance and, in fact, the connection between the material anc the spinitual in the followine description. He uses Uli as a model for all.

Es kbmmt so eine Art ruhige Sicherheit, die bei vieien in dummen Stolz ausartet, Uber cen llenschen, wenn er angehangt hat an der Welt, das heisst, wenr er Fruchte seinen Arveit, Frtras seiner rirdfte vorgespert, Vorrat gewonnen hat auf llinftige janre... und in dem Masse, als en wirklich zufrieden in seinem Inwendigen wird, wird er auch zufrieder rit seinen Meisterleuten. lind je merr er zu etwas $\mathrm{kBmm}$, unsomehr erkennt er den iert der Dinge, huset (spart) richt nur fin sich, sondem es reut ihn lberhaupt, etwas zu vergeuden, er huset also auch den leisterleuten, um so zufrieoener worden diese auch mit ihm. Es stellt sich sein Name fest: er ist ein hauslicher (sparsamer), arbeitsamer Eursche. 66

It is made very ciear here that the peace and contentinent that makes the fertile soil of spirituality is derived from the secondary virtues, in this case thrift and industriousness. These two, as well as other secondary virtues, are now comprehended by UIi. Gotthelf makes sure the reader does not miss this point. He in essence tells the reader how Uli has achieved his degree of success with an expectation that the reader will take this example to heart and perhaps apply it in his or ner own life.

${ }^{66}$ Gotthelf, S4ntIiche ierke, 4:92-3. 
UIi has now certainly increased in faith but is still lacking in charity, which is considered the supreme primary vintue. So that vIi can leary this virtue of pure love, the rovel presents a seemingiy worldiy condition. Uli thinks about marriage. Two of Johannes' maids would like to have him, since he is now a respected person. The one, Stini, is described as ugly but industrious and thrifty. She would have loved to have a husband but could only show her love through rough behavion and criticism. The other one, Ursi, was frivolous in both her behavior and arpearance. She was constantly pringing, didn't like to work or practice thrift.

These two women recognize each other as rivals in their quest for UIi and are constantly at odds with one another. The whole matter becomes ludicrous as both girls vie for Uli's favors and attention. They are literally at war with one another, continuously undermining each cther's efforts. This hampers the work as well as the cooperative spirit on the farm. The wrole matter is finally finished when the two, dripping with liouid manure, are wrestling in the dirt. This farcical situation brings UII to the realization that neither one of them would be desirable as a wife and could not bring him happiness. Stini portrays the negative aspect of the secondary virtues. She carries them to extremes without any relation to the primary virtues, especially in this case the virtue of love. "Ir werde noch anders mussen husen lemen, sagte Stini." 67 For Stini thrift is an end in itself and there is no trace of a real feeling of love toward ${ }^{67}$ Ibid., 4:94. 
lii. Fere Gotthelf shows that the secondary virtues in and of

thenselves cannot bring happiness nor consequent salvation, yet they are still essential.

Ürs likewise possesses no real sense of value for the secondary virtues and therefore only a warped idea of love, a fanciful, unrealistic notion of what love really is. Neither she, nor Stini really understand what brings true happiness: namely, the use of the secondary virtues to attain the primary virtues and gain salvation. Through the embamassment these two women caused themselves and Uli, he learnea there was more to choosing a wife than he had thought and again he has to have patience. iove cannot be forced nor should it be superficial.

With Johannes' help UIi receives a more profitable position as foreman on a farm by the name of Glungge. This, as the name suggests, is a very chaotic place. UIi, after ten years with Johannes, now has a new master, Joggeli, a cousin of Johannes. This Jogeeli is the antithesis of a Christian master and trusts no one. Through various devices he constantly tries covertly to tempt Uli into acts of disloyalty, but he fails. He doesn't support Uli, even though the other servants cheat Joggeli out of goods and time. Several times UIi considers quitting but ends up bringing order to the Glungse. Above ail, he remains totally loyal to his new master, in spite of that man's treacherous behavior.

Two of Joggeli's servants are let go after Uli gives an uItimatum: either he goes or they. These two were lazy, rebellious, and disloyal. Through these characters Gottrelf shows us once again that without 
secondary virtues there is no reward. After their dismissal, they wait around the area, believine that everything would fall apart withcut them on the farm. Howeven, no one comes to ask them back. "Der alte Karrer unc der Melcher wenderten endich ir die Weite hoffnungsios, nachdem sie in der Nuhe unsonst Flatz Eesucht." 68 without the secondary virtues they are also without the primary virtue of hope. The positions promised them by others who incited them against Uli never materialize. Cotthelf makes it quite obvious here that what these two had was not faith but a false belief. What then constitutes the difference between true Christian faith and a false belief for Gotthelf? True faith is based on virtuous behavior. Consequently, the servants' belief was false since it was not based on virtuous behavior. Their belief in cthers was totally misplaced. Just as Uli, who based his faith on the positive outcomes of virtuous behavior, had realized positive results therefrom, so, on the other hand, sad the Karrer and Melcher realized nezative results from their placing their less than Christian faith in unvirtuous behavior. No farmer wants to hire pecple who fall so readily into disloyalty and rebellion. There is no future for them in this region. In short, they are Uli's antithesis, they do not value or Iractice any secondary virtues, consequently the primary virtues are lost to them, and certainly any positive relationship with God and salvation is out of the question.

Uli also has his faults still, especially when material progress is a consideration. He is preoccupied with the possibility of marryine $68_{\text {Itid., }} 4: 199$. 
Joggeii's daughter and thereby inhexiting the farm. Tre daughter is a foolish, self-centexed, clumsy, and lazy girl. And yet the money Iures Uli toward her. This develops for some time and it appears that VIi will achieve his goal. However, Elisi, the daughter, only uses UIi to satisfy her vanity until someone else, who in Elisi's eyes is Uli's better, comes alons and takes adventage of that selfsame vanity for his own benefit. This is a scheming cotton merchant who wants to abuse the farm to ermich his coffers. Elisi's subsequent marriage to this fellow ruins Uli's dream of acouisition of the farm.

This situation couid very easily be interpreted as ironic since Uli gets the farm in the end aryway. Yet Cotthelf's message is again that the material eain in and of itself does not lead to happiness. Had Uli received the fam by way of a marriage to Elisi, he would have acquired it by"default. His Heiligunesprozess, consequently, would have been interrupted, the ro of the secondary virtues dimirished, and he would not have been led to experience the primary virtue of love. True happiness and salvation would not have been accessible to him.

It is finally through Vreneli, the maid, that Uli finds love. She is Uii's female courterpart as far as the functions and needs of the farm are concerned. She manages the housenold while tij manafes the livestock and the crops. Cotthelf describes Vreneli almost totally in

a context of secondary virtues:

Vreneli war von den Leuten, die, sie mugen anrlhren, was sie wollen, immer ein sauber und nett Aussehen haben,.... Mit Fragen und Verweisen wurde keine Zeit verloren. Es schien als ob dem Madchen, sobald es aufstehe, das ganze Tagewerk klar und geordinet, wie eins nach dem ariern komne, vor Augen stehe, so dass es nie 
vergebene Gيnge Eab, man nie hưte: "In ha nit gsinnet, ih ha nit denkt, in ha nit gneint." 59

Gotthelf then explains how 11 i ard Vreneli set an environent of tctal cooperation. Thene is a unity ir spirit and purfose, as a result of which everything prospers, making the suspicious Joggeli extremely uncomfortable.

Vreneli embodies several secondary virtues: cleanliness, unity, order, and implicitly loyalty and patience, the latter especially toward Joggeli. In this sense she is the transformed Uli's mirror image. It should be no surprise when these two confess their love toward each other. The fact that their behavior conforms to the secondary virtues brings them to the happy condition of love. Modesty, devoutness, and industriousness help them achieve this end.

Of those three virtues last mentioned, much has already been written concerning UII and modesty. His transition has been seen. Vreneli never had to undergo such a change; she is and was the epitome of this virtue. Nor is it necessary to show her changing in this respect. The story is, after all, about Uli's development. Gotthelf, however, does not show us a sentimentally romantic context in which she displays a stereotypical feminine modesty. Instead, he exposes a self-assured individuality which comes from making the virtuous lifestyle one's own. This is not to be confused with self-righteousness, but is an assertive frame of mind, based on solid convictions of moral right and wrong. An example is when Elisi's husband makes sexual advances toward Vreneli who becomes indignant and grabs a piece ${ }^{69}$ Ibid., 4:262. 
of wood to beat him with!

Wie eire gluhende Siegesglttin stund es da mit dem Scheit in der Hand oder wie ein Engel mit flammendem Schwerte vor dem Paradise der unschuld und rief dem fliehenden, blutenden Baumwollenhändler nach: "Weisst du jetzt, wie ein Bernermeitschi akkordiert, und nit was es den Akkord unterschreibt, du keibelige Uflat!?0

It is clear what she stands for, and her righteous indignation and subsequent treatment of the merchant is greeted with laughter from the entire household. After he calls her a liar when she exposes his intentions, she throws the piece of wood at him, which knocks out three of his teeth. The laughter that follows this act also becomes evidence that a foiled dishonorable act lesves one lookins the fool. Gotthelf's talent for comic relief, in an otherwise serious situation, makes the moral lesson he offers more palatable. There remains no doubt that the secondary virtue of modesty and moral purity in general are not to be taken lightly. It is clear that a love relationship between man and woman " for Gotthelf much more than the mere physical aspect or even the physical-emotional aspects of many writers. For true love to develop, it has to be based on secondary virtues. That is not to say that there is no room for physical attraction. But if we define the erotic as the purely sexual desires, then erotic nuances between Uli and Vreneli do not exist. In contrast to Uli's supposed love toward Elisi, the love toward Vreneli is the true, loyal love, without any false notions, not hampered by any false motives.

Uli now has progressed beyond his perception of the secondary virtues as an end in thenselves, that they, without being coupled to 
the primary virtues, car bring happiness. Uli declares his love first. But Vreneli, even trough she loves Uli, fears that if Uli disappcints hex in her expectations of what a marriase should be, she will have lost any further chance for a loving relationship in this life. Vreneli, being a model of virtue, brings forth Gotthelf's idea that marriage is an unequivocally life-long commitment. Being orphaned, and having Joggeli to constantly remind her of her "place", she feels she now has only one chance for a true love relationship. If she marries and becomes unhapy, there is no way out. For that reason she tries to suppress her feelings. Uli implores, saying that if Vreneli will refuse him, he will ask nothing more of life and he will leave, as far away as possible, and no one is to know whereto. With watery eyes he stands in front of Vreneli whose eyes also dampen. The scene is described as follows:

Da sah Vreneli zu ihm auf, d. Augen wurden ihm feucht; aber un den Mund zuckte noch der Spo: und der Trotz, die niedergenaltene Liebe brach auf und begann durch die Augen ihre leuchtenden Strahlen zu werfen, whähend das jungfrululiche Widerstreben die Lippen aufwarf als Schanze gegen das Ergeben an die mannliche Zudringlichikeit... Allein des Mudchens Kraft hielt nicht aus. Das Madchen fiel an Ulis treue Brust und brach in lautes, fast krampfhaftes Weinen aus. 71

Vreneli explains that while she was a child no one loved her and she was always in the way. She couldn't recall how many lonely tears were shed. She longed for someone to love wholeheartedly, someone with whom she could share both joy and sorrow. Never having found such a friend, she would never consider marriage, unless it was the type of relationship where the husband would remain loyal in life and death.

$$
{ }^{71} \text { Ibid., 4: } 335
$$


She has rot yet found someone to inspire that kind of faith. She says:

Uli sei ihm lieb, sej. in schon lange lieb, mehr als es sagen sollte; aber diesen Glauben $z u$ inm habe es noch nicht finden konnen. Und wenn es diesmal getuscht widrde, wenn Uli nicht die rechte Liebe, die rechte Treue fur inns hätte, dann wäre ja sein letztes Hoffen dahin, dann wignde es keine mehr firder, dann musste es ungllicklich sterben. ${ }^{2}$

The concept of love is here based on the secondary virtue of loyalty. In fact, Gotthelf, in the above sentence, seems to almost make them synonymous. One without the other is inconceivable for a state of happiness. Only through a loyal love does one find happiness. This is, after all, the title of the novel - Hie Uli der Knecht Elluklich wird. Such a love also brings unity with God.

Vreneli sees the hand of God in her life. The connection between her virtuous life and receiving love is made without equivocation. Speaking of God, Gotthelf puts the following into Vreneli's thoughts: "Hatte er den Ratschluss wohl gefe:, weil es getreu geblieben bis dahin und von der Slunde sich unbeflest zu erhalten gesucht, nun auch seines Herzens Sehnen zu stillen, ihm eine treue Brust zu geben, ..."73 Furthermore, she also asks in her own mind if it wasn't God who offered her Uli and the adjectives treu and ehrlich appear again in relation to Uli. She sees Cod's will in everything that has happened so far: that Elisi married someone else, trat Uli remained on the farm despite Joggeli and his antics. All these questions allowed her mind to wander in a daydream toward an affirmative answer.

An interesting aspect of this affirmation is that the thought

$$
\begin{aligned}
& 72 \text { Ibid., 4:336. } \\
& 73 \text { Ibid., 4:338. }
\end{aligned}
$$


process that Vreneli undergoes begins when she questions, "warum doch wohl der Vater, der die Liebe heisst, so arme Xinder leben lasse, die niemand hatten auf der Welt..." 74 unce more the reader is reminded that both Uli and Vreneli are orghans. They had no one to love them in their early childhood. The question which Gotthelf raises is vital to an interpretation of the Christian God. It is a part of the question of theodicy and is thought abcut by anyone who scrutinizes Christian theology. The significance here is that Gotthelf quickly turns Vreneli's thoughts to the positive rossibilities, reenforcing faith and hope in the possibility of love as a result of loyal, virtuous life. This love then becomes an affirmation of God's pleasure with Uli and Vreneli. This is substantiated by the calm and peace which attend Vreneli after she imarines herself married to $\mathrm{Uli}$ and in charge of a large household. Gotthelf then again, using one of his realistic literary devices, brings Vreneli $i$. to reality after she has her "vision".

Es wusste nicht mehr, dass es im whgeli fuhr es war ihm so leicht, so wohl ums Hexz, $\equiv$ ls ob os bereits atme in jener welt, wo keine Sorge, kein Leid mehr ist; da rollte das wagele ${ }^{\prime} n$ uber einen Stein. 75

Gotthelf shows us Vreneli's innocence, her unity with God. He also shows us that virtuousness is rewardec by lod because it leads one to God. To further prove the point of my thesis that Uli's love toward Vreneli is a prototype for a Caristian love and not just the sensual eros which unites most young couples in a relationship, I rely on the

$$
\begin{aligned}
& 74 \text { Ibid., 4:337-8. } \\
& 75 \text { Ibid., 4:339. }
\end{aligned}
$$


following quote of Gotthelf's narrative interjection (one of many such irterjections he uses throughout his work):

Wenn jemand eine liebe Seele gefunden und an sich gebunden nicht nur für diese Zeit, sondern auch fur die Ewigkeit, soll es ihn dann nicht hin zu dieser Seele ziehen mit Himmelsgewalt, soll es ihn nicht in ihre fugen, dis Tore der Seele, hineinziehen, um das Gefluhl lebendig zu erhalten, eins mit einer Seele zu sein in zeit und Ewigkeit? Dieses Einswerden mit einer Seele von ganzem Herzen, ganzem Gemlte und allen Kraften, in welcher Vereinigung alle Ichsucht untergeht, ist das nicht auch ein Vorldufer des Einswerden mit Gott, welchem ebenfalls unsere Selbstsucht zum Opfer fallen muss??5

Indisputably is it written, black on white, that such a Christian matrimonial love will lead to God. The question is obvious ly rhetorical. This true and risht love relationship allows both individuals to practice faith, hope, and charity, supported by all the secondary virtues. They do not hincer each other in the way toward their salvation; they help wherever possible, are conscious of each other's goals, and have similar intentions, i.e. purposes, in life. Such a becoring of one, such a unity, creates for them Heaven on Earth. Gotthelf coes not linger in an idealistic never-neverland. He wants to actualize, to realize the Christian ideals. One only has to remember the stone over which the cart rolls. Gotthelf holds the ideal in front of our eyes but is not so naive as to think it will become reality without effort, just as he is not willing to relegate them to a pessimistic notion of the unattainable and therefore impractical, or something for an after-life. Many people are of the same opinion as Northrop Frye when he says, "Many of Jesus' exhortations are evocations of a world very different from the one we live in, so that we may find

$$
{ }^{76} \text { Ibid., } 4: 342 .
$$


them unpractical or exaggerated as guides to practice." $77^{r}$ Frye then explains in the very next sentence that it is the vision of an "innocent world" that is to be the guide to practice. Gotthelf's concerm, however, is for the here and now. He presents us with practical applications. This, in and of itself, could very well have caused a good portion of the difference in point of view between himself and his pietistic critics.

Uli receives the Glungge as tenure and becomes a tenant farmer. Even the suspicious Joggeli knows no one better to lend his farm to. once again the secondary virtues are credited with Uli's reception of the farm. "So rlickte in banger Stimmung die Zeit heran, wo Uli das Leben Ubernehmen sollte, das ihr das Zutrauen um seiner Anstelligkeit und Treue willen Ubertrug. "78 This last sentence bears out the fact that reople have placed their trust, i.e. feith in Uli because of his skillfulness and loyalty. Virtuous behavior brings with it a new life, a definite break with the past. This represents a spiritual breakthrough symbolized by his receiving the farm as a manifestation of the significarce of this step.

In addition to those already mentioned, there are still numerous passages which point toward a unification with God through the secondary and primary virtues. It will be sufficient, however, if we focus attention on a few essential ones which summarize the thesis. The minister speaks with $U 1 i$ and Vreneli after they are married.

77 Northrop Frye, The Great Code: The Bible and Literature (New York: Harcourt Erace Jovanovich, Fublishers, 1982), 219. ${ }^{78}$ Gotthelf, sumtliche borke, 4:357. 
In the following excerpt lies some proof to the formula: secondary virtues lead to primary virtues, which lead to God. In this case, it is trrift which leads to hope, which leads to godliness. Not the fact that thrift has allowed Uli to save money in and of itself is important, but the qualities coupled with thrift that allowed him to gain the trust of others is of great significance. The emphasis is still on Uli's growth, his progress toward salvation.

"Ich habe gehbrt," sagte derselbe, "du seiest $z$ weg, bekommest ein gutes Lehen, eine sute Frau und habest schbn Geld erspart. Das tut mir gar wohl, wenn ich eine the einsegnen kann, von der ich hoffe, aass sie in dem Herren bleibt. Dass du etwas erspart, ist nicht die Hauptsache; aber du huttest es nicht, und man hatte dir nicht so viel anvertraut, wenn du nicht brav und fromm wärest, und das ists, was rich eigentich recht freut. Das Weltliche und das rechte Geistliche sind viel nuher beieinander, als die meisten leute glauben. Sie meinen, um recht wohl zu sein auf der Welt, musse man cas Christentum an den Nagel hangen; und das ist gerade das Cegenteil:..."79

It is, according to Gotthelf, after all the true Christian who becomes happy, the ore who acquires the necessary Christian virtues, whose well-being and salvation can be achieved simultaneously. Both are based on the same principles, the same necessary qualities acquired by practicing the virtues.

To be Elucklich has nothing to do with Gluck haben. For Gotthelf all rewards are blessings from God and have to be recognized as such before true happiness is attainable. There is no allowance for a germanic fatum or a secular "stroke of luck". Nor is it the simplistic and unrealistically portrayed, infallibly righteous actions of the protagonist, set off against a villainous antagonist, such as in the works of the later American writer, Horatio Alger. Gotthelf shows us

$$
{ }^{79} \text { Ibid., 4: 375-6. }
$$


people with definite faults, he shows life as a struggle in which each individual has to exert his or her ow enereies and yet, having done so, recognizes God's hand in his or her life. There is no room for "Iady Iuck". The minister, in talking to Uli says:

Aber eben das ist das Ungluck, dass die Leute durch das Gfell gllucklich werden wollen und nicht durch frommes Leben, bei dem der Segen Gottes ist. Da ists nun ganz recht, dass die, welche nur auf das Cfell warten, von Gfell betrogen werden, bis sie wieder zur Erkenntnis kommen, dass am Gfell nichts, aber an Gottes Segen alles gelegen sei.

For Cotthelf it is a world that is put in order by God, there are no coincidences, everything has a purpose. This means there has to be a reason for Uli's success, it was no arbitrary cccurrence. From the above quote the idea can be deduced that devoutness becomes the circumference of the circle of secondary virtues. Even though loyalty is the virtue focused on more than any other, and, according to the author, is the dominant theme, there seems to be no other single dominant virtue. They are all important and have a significant role in UII's progress, all being inextricably connected one with another.

The minister admonishes the bride and the groom to walk on the path of love, gentleness, and patience, "denn glaubt es mir doch, das rechte weltliche Gllick und das himmlische Gluck werden akkurat auf dem gleichen Wege gefunden." 81 Again the virtues bring both happiness in this life and salvation in the next. They lead one to God. Being led to God through the virtues, especially havine once attained the primary virtues, is what brings happiness.

80 Ibid., 4:376. The word Gfell means the same as bIindes GItlck. 81 Ibid., $4: 4: 381$ 
To funther substantiate the earlier supposition that this is a Christian love, a charity in its purest form that is to be typified by the union between $\mathrm{UI} i$ and Vreneli, the minister addresses the virtue of love. "Und wie die Liebe den Heiland gesand, Liebe inn ans Kreuz gebracht, so muss auch bei euch die Liebe tatig sein; sie ist die Kraft, die uber alle Krafte geht, heilet und bessert." 82 How is love active? Through practice of the secondary virtues. Through them does one arrive in the realm of love and thereby in the Kingdom of Heaven. This blessed state of happiness, this heaven on Earth, was for Gotthelf something attainable, something to be worked for.

The last page of this novel is the culmination of all the points made up to now. Two orphans, one a seeminEly hopeless, incorriEible servant, over years of struggle and growth through acquisition of virtues, have found true love and a unity in God. This, in turn, leads them towards a life of happiness. "... und es stunden wiederum die Sterne am Himmel, als nach recht inrigem $A$ hschied, wie er selten von Nichtverwandten Eenommen wird, der mutige Kohli ein Elluckliches Faar davonfuhrte - dem Himmel zu." 83 This is no romantic "all is well that ends well". There are still many problems and struggles that follow in the second part of the Uli novels. It is an affirmation that Uli and Vreneli are on the right path, although not yet there. It is not a falling in love and getting married and living happily ever after of which fairy tales are composed. We have witnessed the outward

\footnotetext{
${ }^{82}$ Ibid., 4:381.

${ }^{83}$ Ibid., 4: 387 .
} 
manifestations of a sanctification frocess. The novel is a guidepost for all those who want to attain true happiness, a happiness on a solid Christian foundation.

This book was after ail intended as a lektlur which the final observations of Gotthelf attest to.

$\mathrm{Ja}$, lieber Leser, Vreneli und Uli sind im Himmel, das heisst, sie leben in ungetrlbter Liebe, mit vier Knaben, zwei Madchen von Gott gesegnet; sie leben im wachsenden Wohlstande, denn der Segen Gottes ist inr Gfell, ihr Name hat guten Klang im Iande; weit umher stenn sie hoch angeschrieben, denn inr Trachten geht hoch, geht darauf, dass inr Name im uimmel angeschrieben stehe!

Merke dir das, lieber Leser! 84 
In order to try to understard cause and effect, influences, and ideas, the science of literary criticism has developed certain labels to identify similarities within certain creative epochs. The label within which Gotthelf falls is the Biedermeier. The minds of those who are schooled in the literary movements will, at the mention of this word, bring forth some definite images, descriptive of this period. Understanding Gotthelf means, however, to suspend those notions. His style, his motivation, and his ideas do not lend themselves easily to classification. Often a critic classifies him, only to find that the arguments and assumptions have to be revised or finds someone else revising them.

'that, in fact, can be said about Gotthelf's genre and more specifically how this genre relates to $\mathrm{Uli}$ ?

To begin with, it would be helpful to define him as an epic writer. Muschg places him nebulously in the "...nachklassischen und vorburgerlichen Jahrzehnten des vergangenen Jahrhunderts....85 and calls him "...den grbssten Vertreter des polemischen Zeitromans..." 86 He 85 Nuschg, Geheimnisse, Vorwort, VII. ${ }^{86}$ Ibid., VII. 
was not a poet, although he would like to have been one. The reason for this is his topics, his motives in writing, the people he wrote about, and the language he used. Exploring this further, Northrop Frye, explaining ideas of vico, writes:

Each age froduces its own kind of language, giving us three types of verbal expression that Vico calls, respectively, the poetic, the heroic or noble, and the vulgar, and which I shall call the nieroglyphic, trie hieratic, and the demotic. These three terms refer primarily to three modes of writing,... The hieroglyohic phase, for Vico, is a "poetic" use of language; the hieratic phase is mainly allegorical; and the demotic phase is descriptive. ${ }^{8}$

The word demos refers to the common people. The common people of the Emmental were involved in farming. Since they are the subjects of and material for Gotthelf, his writing had to necessarily be demotic, i.e. descriptive and therefore epic. Even though there has been experimentation with "pcetry of fact", can we imagine an allegory or poem in descriptive language? Instead of the Eauernroman: Wie Uli der Knecht Flllcklich wind we would have an Ode an die Treue. This also, of course, does not satisfy Gotthelf's intentions in writing. This is why he failed at poetry. He wrote to teach and had to use descriptive, demotic language. If he had tried to force his purposeful, descrintive language into allegorical or poetic form, it would have had a satirical effect and would leave the reader pedagogically unaffected. This is especially the case in UIi where the virtues are central and the work being intended as a lesson.

Having defined Gotthelf as an epic writer, we now have the basis 87 Northrof Frye, The Great Code, 5. 
for looking at what kind of epic writer he was. Adolf Bartels sees him as the successor of Auerbach and the latter's Dorfgeschichter, yet having transcended him aesthetically and in his talent for portraying the Iife of the people. 88 The term Dorfgeschichten, stemmins from Auerbach's work by that name, was soon generalized into a genre into the parameters of which some wanted to confine Gotthelf. He, to the contrary, objected to being placed into this new genre concept. Werner Hanl tells us:

Vor allem der Titel Dorfgeschichten wurde bald zu einem Gattungsbegriff verallgemeinert... 1850 schlug inm sein Berliner Verleger Julius Springer vor, eine keihe von Erzuhlungen unter den Titel "Schweizerische Dorfgeschichten" zu verbffentlichen was Gotthelfs hutorstolz allerdings nicht zuliess. 89

Gotthelf was no epigone. A much better description of Gotthelf's Uli is a Bauernroman, as also described by Hahl. 90 It definitely falls into the category of a novel and topically it deals with farming life. But we know it deals with more than just farming. Here again we see the difficulty in classifyine Gotthelf's work. What he intended as a lesson of virtuous living evolved into a novel about such living. It is not overly didactic, however, but full of vitality and joie de vivre. It does not portray a somewhat stale and bourgeois world like the later Gustav Freytag in Soll und Haben, even though dealing with similar

88 Adolf Bartels, Jeremias Gotthelfs ausgewhlte werke in zehn Bünden(Leipzig: Max Hesses Verlag, 1908), 1:68.

89

Werner Hahl, "Gesellschaftlicher Konservatismus und literarischer Realismus," in Realsimus und Grlnderzeit: Manifeste und Dokumente zur deutschen Literatur 1848 - 1880(Stuttgart: J.B. Metzlersche Verlagsbuchiandlung, 1976), 1:51.

90 Ibid., 1:48. 
virtues. 91

The spiritual level of Uli is not even hinted at by the above term and yet we would feel very uncomfortable without a label for this work. Erziehungsroman is another that has been used. Heimatdichtung could also apply in certain respects. Each one of these terms have been defined by scholars based on a comparison of different works by different authors. When one takes a work out of the context of this comparison, it becomes obvious that aspects of all these definitions can be found, but none is totally adequate for that particular work. It is virtually impossible to deal with the complexity of a particular work, when we involve the notions of a simplified generality. Consequently, to describe Uli as belonging strictly to any one of the mentioned or unmentioned terms confuses us and hinders us from coming to terms with Uli. Again we must be cautious about preconceptions and formulated notions which, as helfful as they are when dealing with types, may only confuse and befuddle when dealing with particulars.

It should not be our intention to come up with a new and independent genre for Gotthelf. That would only mean adding to the already existent confusion. It is important, however, to consider the factors that make rp UIi. In order to do this, we have to base our communication on jargon which is not always so clearly defined that nuances of differences won't appear which cause a

91 Virtues such as order, loyalty, honesty, and attention to duty are valued in this work. Gustav Freytag, Soll und Haber, 85th ed. Leipzig: Verlag von S. Hirzel, 1916), 1:193, 200, 254. 
variation in the understanding of different individuals. This is best exemplified by two opcosing viewpoints in regarding Gotthelf as a realist. Schmidt claims he is "der freieste Humorist, den unsere neue Dichtung kennt," and the critic of ralism, Gottschall, says,"der Uli sei eine in Romanform gebrachte Dienstbotenordnung." 92 As Hahl says on that same page, "Die hahrheit liegt in der Mitte." 93 The point is that to say Gotthelf was a realist may mean different things to different people. Therefore, we cannot understand Uli without looking at the essence of the vriter as well as the product.

It is the essence of the writer which gives the reason for Uli's existence. To come to terms with any part of a genre, we have to understand the author's purpose for writing Uli. This purpose has already been introduced in the second chapter, as quoted from the foreword to Uli der Pachter. We need to understand that Gotthelf was a driven man. He at one point said, "Ich nahm mein Herz in beide Hunde und schmiss es aufs Papier." 94 He wrote very purposefully and in doing so, drew on his life's experiences. He was never concerned with literature exclusively as an artform but as a medium for expressing his ideas, his beliefs and also his emotionality. It was a safety valve for hinself as an indivicual. He said, "Begreife nur, dass ein wildes Leben in mir wogte, von dem niemand Ahnung hatte, ...dieses Leben musste sich entweder aufzehren oder losbrechen auf irgendeine Weise;

92 Hahl, Realismus und Grlinderzeit, 57. 93 Ibid. , 57.

94 Gerhard Fricke and Volker Klotz, Geschichte der deutschen Literatur, 15th ed. (Llbeck and Hamburs: Katuiesen Verlag, 1971), 272. 
es tat es in der schrift."95 Feople have asked how a minister can write such "worldly" things. The answer is that although he didn't live them, he understood them at an emotional, psychological, and spiritual level. It is the inmersion of the author's soul in the spirit of the people he was writing about which led him to be able to write so realistically and with such depth and insight. Fricke/Klotz write:

Seit Grimmelshausen, dessen dualistischer Gebrochenheit jedoch die urwhichsige Lebenskraft und Lebensfulle Gotthelfs weit uberlegen ist, gab es und sibt es nichts Vergleichbares fur die oft unbarmherzige Treue und Wahrheit, mit der die Wirklichkeit des kenschen von der Oberfluche bis in die Tiefe erfasst wird. Hier, wenn irgendwo in der Dichtung, ist der Eauer lind in ihm der liensch, wie er var und wie er ist, Gestalt seworden. 96

It is no wonder then that this knowledre of the human soul comes through in his writing. Given the above information, it is also understandable how in some critics' minds Gotthelf was perceived as a naturalist.

Gotthelf was no naturalist as such, although there were naturalistic aspects to his writing. He wrote UIi pedagogicallyscciologically motivated, portraying a Christian work ethic surrounded by virtues leading people on a path toward sanctification. Had he done this purely within the confines of romanticism, as that movement is generally defined, an idyllic image would have evolved which would make the work mainly hieratic, create an insurmountable distance between the intended readership and the work, and at last make the work

$$
\begin{aligned}
& 95 \text {-Ibid., } 272 . \\
& 96 \text { bid., } 272 .
\end{aligned}
$$


unielievable and pedagogically ineffective. He had to reach into the world of the farmer, including the dung, both the literal and metaphorical sense of that word, if he didn't want to alienate himself from tinose he wanted to teach. That the work had its initial great success in Germany, i.e. Prussia, was a result of and not an intention of the work. We can feel very comfortable with Werner Glinther's perception of the degree of realism and naturalism which we allow to be appiied to Gottinelf in general and Uli in stecific.

"Realismus" und "Vaturalismus" sind im Grunde mehr ein soziales und etrisches als ein aesthetisches Froblem; sie bezeichnen vor allen das Hinuntersteigen zu Nenschineitszlassen, die man zuvor erhbnter literarischer óymbole nicht wlirdig glaubte, weil man das Reinnenschliche in innen noch nicht zu erkennen vermochte. So aber nur so - aufgefasst, ist Gotthelf ein Realist und ein Naturalist, einer der ersten, der erste wirkliche vialleicht. Seine geniale Leistung war es, als weithin Erster in Bauern den ewigen Menschen zu sehen und aufzuzeigen, den ewigen Menschen in den Bauern hineinzusehen und einzugestalten, und dies mit einer Selbstverstundichkeit, die im Leser dep Eindruck der Anschauungstreue nur vermehren konnte. 97

Gotthelf, of course, sees a definte nobility in the famer, which does lend an allegorical aspect to Uli as a type for all maniind. The sinful Uli acquires virtues and progresses toward salvation. Gotthelf's faithful adherence to the dialect and his realistic replication of life in the Emmental keep some from seeing this allegorical aspect, specifically his pietist critics. It is, after all, the higher literary symbolism through which this work becomes more than what Gottschall denegratingly refers to as a Dienstbotenordnung in Pomanform. The eternal aspects that Gunther refers to are the ones we are also considering as spiritual. Something 97 Gunther, Neue Gotthelf-Studien, 72. 
truly spiritual transcends time and space and is therefore also eternal. In that sense then, the virtues by which $u l i$ is sanctified are also spiritual and eternal. This also helps us understand what Gotthelf means when he says that "das rechte weltliche Glllck und das himmlische Gluck" are found in the exact same way.

Gotthelf's naturalism and realism are used on a descriptive level in relation to the sociological and ethical problems, according to Gunther. We can then postulate that the aesthetic element of Uli is the same as what lends the spiritual level to this work. It lets the work speak to all mankind at whatever time, i.e. it makes the work eternal. This can account for Uli making the "bestseller list" in Berlin, a cosmopolitan atmosphere far removed from the provincial Immental. There is more than just curiosity about the life of farmers that motivates people to read this work; there is an eternal/spiritual aspect to it which gives it a place for study in the aesthetic realm of the field of Germanics.

As already mentioned though, Gotthelf himself had little or no concem aboit the process of aesthetics. His publishers complained about the many mechanical errors in his manuscripts that they had to correct. Not that Gotthelf didn't have the capabilities to correct such errors, but he wrote with such fervor that he produced an immensity of writings and did not concern himself with what to him was trivial. Gotthelf "wanted to throw his heart on the paper"; he wrote about what concerned him, what affected the people he dealt with as a minister.

It is exactly this realistic utilitarian tendency which someone 
like Gottfried Kelier, who greatly respected Gotthelf on the whole, denounced as unartistic. No one yet has acclaimed Gotthelf as a definitive master of aesthetics, nor would we pursue such a misdirected task. The aesthetic is more the process of the writing, the words used, in what order, and the consequential results thereof. Gotthelf was not so much concerned with the process as with the effect. Even Keller acknowledged that Gotthelf achieved the desired result with uli. But he does criticize Gotthelf's process.

Fragen wir nach dem Frinzif, zu welchem hinauf und durch welches Gotthelf seinen "Uli" gerettet hat, so finden wix ein strenges, positives Christentum. Darlber ist mit ihm nicht zu rechten... Aber die Art und Veise, wie Gotthelf seinen zweck verfolgt, ist zu verwerfen, nicht nur weil sie pfuffisch und bysartig ist, sondern auch weil sie seine Schriften verdirbt. 98

It is the aesthetic which is revered by Keller, but for Gotthelf it is in and of itself unimportant. The latter's position toward the literary artform was to use it as a means to an end. That is not to say that his perhaps didactic points cannot be made with art. They are not mutually exclusive. Although Keller feels they detract from the artistic element, there is much evidence that Gotthelf uses the artistic to achieve his points. Scholars such as Neuenschwander show there is no lack of literary highpoints.

Die glucklichste Ubereinstimmung der liebenden Erregung zweier Herzen mit dem dichterisch geschauten Bild stellt jedoch Vreneli's Begegnung mit Uli am morgendlichen Emunnen dar. Die Szene ist von geradezu klassischer Schonheit und Einstimmigkeit.99

Keller also admits, "An epischen, lyrischen und dramatischen Momenten

$$
\begin{aligned}
& 98 \text { Keller, S4mtliche Nerke, 3:927. } \\
& 99 \text { Neuenschwander, Ordnung, } 130 .
\end{aligned}
$$


der schbnsten Art fehlt es auch nicht."100

What we are sayine then is that $\mathrm{UIi}$ is not an aesthetic masterpiece if measured in comparison with the classical humanist demigods, Goethe and Schiller. His use of language alone would prevent such a comparison. Not just in how it is written but what is written makes $\underline{\text { Uli }}$ a literary work of great significance. From a classical humanist vantage point one would have the tendency to find much to criticize about Gotthelf's concept of art. That is perhaps the major difference between Kellex, who shows greater ties to that tracition, and Gotthelf, as kriters. Gotthelf's concept of art cannot be treated superficially if we stay true to the thesis, because it is his approach to writing which ultimately enables bim to portray the sanctification of a human being through virtuous behavior in his own unique way.

Gotthelf saw in literary art a mediun to educate the people. This medium was to serve in furthoring Christianity. In a case where this purvose is missed, art becomes an Ersatzreligion and looses much of its overall worth. For Gotthelf's active, virtuous Christianity, much of the literary art was too alienated from reality and dia not really serve the human interest since it added nothing escential on the path toward sanctification. Therefrom follows Keller's criticue. The two authors were diametrically opposite in their perception of the role and function of art. Keller revered literary art as a human accomplishment while Gotthelf viewed it, 
especially in Uli, as an instmument in educatin people toward the sanctification process. It was an extra arm, so to speak, of his ministry. Keller recognizes this and therefore calls Gotthelf "pfuffisch", lookine at Gotthelf's work purely from the perspective of the conventional Kunstbegriffe of literary criticism. For the aforementioned reason Gotthelf's works were created, according to Nuschø, "...ausserhalb aller literarischen Kunstbegriffe, aller konsequenten artistischen voerlegung. "101

It is not that Cotthelf doesn't value literary art. Obviously he used it and is a part of its history. The attitude of people toward art is what concerned him. He saw no redeeming value in art in and of itself. As Muschg explains:

Gotthelf spottet aber nie lber die Kunst, nur Uber ihre konventionelie Verhimmelune im blurgerlichen Eildungs vetrieb. Diese Vergbtzung der Kunst um ihrer selbst willen hält er allerdings flur eine Form des modemen $A$ ber laubens, und er ist uberzeugt, dass sie den Ausbruch einer neuen Barbarei nicht verhindern werde, sondern im Gegenteil ihr Vorspiel sei. 102

Gotthelf then uses art to allow his religiosity to disperse among the people, and he wants to raise, i.e. educate the people toward Christianity through examples of virtue in his novels.

Whether or not this diminishes Gotthelf's aesthetic contributions to literature depends scmewhat on one's own philosophical stance toward the role of art in our lives. Certainly Gotthelf was talented in literary devices and techniques. It is most often his motives for writing and what he does literarily to achieve those motives that

101 Walter Muschg, Jeremias Gotthelf: Eine Einfuhrung in seine Werke. 2nd ed. (Bern und Munchen: Francke Verlag, 1960), 47. 102 Ibid., 48. 
come under attack from the purists who revere literature as an end in itself.

One final quotation by Musche will sum up the attitude of one who values Gotthelf's aesthetic significance and yet is not bothered by the functional thrust of his writings.

Mit dieser Grosse hat es eine ganz besondere Eewandtnis. Ir ist ein religilses und ein echt volkstlumliches Genie, das nicht nur usthetisch gewlurdigt sein will, weil inm die kunst nicht luber dem Leben, sondern im Dienst des Lebens stert. 103

\section{ANTTMTERIALISM}

Through the examination of the text of $\mathrm{Uli}$ we have come to understand that Gotthelf was no materialist in the philosophically defined sense of the word. Yet we have to also understand that he did not reject the worid in which he lived but acknowledged it as a creation of God. As such he revered it and saw human beings as an image of God, although in spotted and imperfect form. He battled the materialistic movements of his day vehemently, especially communism and socialism. Not only did he fight materialism in its institutional appearances but also its individual manifestations, especially where it tosed a threat to human sanctification. Matter as such is not considered evil by Gotthelf; the human disposition toward it, however, may be so. Jespersen explains this position quite well.

In Gotthelf's theology, spiritualization does not come from a denial or rejection of the world, but through a correct use of it...A rejection in the neo-platonic sense is foreign, Gotthelf believes, to the true Christian message. Natter, according to Gotthelf, is not evil in an absolute sense since 
God created it." 104

Evidently the question of theodicy is for Gotthelf not a major concern, as he accepts the goodness of God and also, consequently, the goodness of his material creitions.

The person's position toward the material is the central concern. Uli becones richly blessed, i.e. rewarded, only after he displays the proper disposition toward the material. When he selfishly wants to acquire the farm through a marriage with Elisi, not yet having found love, but being creedy, he fails. Only as he achieved arrival at the virtue of love and establishes a unity with God does he find rightful happiness, incluaine the material aspect. The latter was acknowledged as a blessing from God, as a reward from God, since he was the creator of it, for Uli's and Vreneli's virtuousness.

Secondary Virtues Vis-à-vis Selfishness

Selfishness is the repelling pole of virtue. Since it is the virtues that lead to God, it follows that selfishness leads away from God. The secondary virtues are devalued through selfishness since they create a negative effect in the spiritual realm. We have already established that the material reward Uli reeeives was a reward for his virtuous behavior and serves as a witness to the fact that now Heaven and Earth are bound together. It further serves as a sign that Uli is on the way to Heaven, i.e. his sanctification.

It was because of this old Testament concept of a God intricately involved with both Heaven and Earth that Gotthelf was attackec by 104 Jespersen, Christien Crder, 89. 
Keller, who perceived a Jewish element in the work. Cne can only make such an attack, calling the work Jewish in flavor, if one does not consider the role of the secondary virtues. Gotthelf does not portray a vindictive, punitive, thunde:ing God, as Keller purports, but a Christian God who involves himself directly in the life of ach individual being. This God, through virtuousness on the part of the individual, reveals himself and brings him or her happiness in this life as well as the next; but only then when a person has the proper disposition toward the material. Guggisberg supports this argument that Gotthelf's God is fully Christian. "Gotthelfs Gott straft auch, aber nicht aus Rache, Zorri und Eifersucht, sonder aus Liebe, um die Menschen zur Einsicht, Busse, Läuterung und Besserung zu fuhren." 105 Again, selfishness and greed remain unrewarded. They have no place alongside virtues, if those virtues are to have a positive effect. As already explained in the second chapter, the main reward for practicing the secondary virtues is the building of characteristics and behavior patterns which later put one in a position to receive material rewards as a blessine fron God. That is not to say there are no rich people who are godless or selfish, but they are neither truly happy nor on the path toward sanctification. This connection between the material and spiritual, the abyss between virtue and selfishness, is also affirmed by Maybaum.

Fur Gotthelf ist es oberster Grundsatz, dass die Tugend zum Heil fuhre und nur in Gott die Kreatur selig werden kb̈nne. her die gbttliche ordnung anerkennt, wer betet und arbeitet und tut, "was brav und recht ist", der hat auch ein tusseres Gluck und 
kommt zum Wohlstand, zumindest bleibt en zufrieden mit Gott und der Welt; wer sich aber gegen die Gottesordnung vergeht, hochmltig, Ibermutig, und sejostsuchtis wira, der wird bestraft. Feichtum bringt nur ir verbindung mit Frumigkeit Segen, sonst wird er eine quelle des Verderbens. 106

Cotthelf gives us enough examples of people who have these negative experiences in relation to the material. Elisi, who is very selfish, ends up with an abusive husband and is both as physically and financially forsaken as she is godless. Johannes, Joggeli's son, continually demands money from his fathex because he can't manase his business due to his and his wife's excesses. Jogzeli himself, being totally self-centered, does not seen to have one happy moment and is undone through his own and his children's wrongdoing. Uli is filled with such characters which are set in contrast to UIi and Vreneli, treir loyalty and selflessness.

As we have seen, Uli is not always selfless. When he is selfish, he wins nothing by it. In the first part of Uli's story, when he only thinks of himself, how bad he has it, how he doesn't receive enough pay, and how no one allows him any pleasures, he makes no spiritual or material progress. Only after he shows an interest in his master's work and possessions as though they were his own, as he acquires the secondary virtues of loyalty and thrift as opposites of selfishness, does he make spiritual and material progress, which two remain bound together throughout the work.

Secondary Virtues Vis-à-vis Avarice

Avarice, like selfishness, is a destructive characteristic. It 106 Maybaum, Gottesoramune, 29. 
is true that hope for raterial possessions is an incentive for Uli, but avarice is never rewaraed. What Karl Fehr says is true: "Im Vergleich zu Vreneli bleiot $U$ li stets mehr an den realen zweck gebunden, und seine unzweifelhaft starke Hingabfuhigkeit wird andauernd von Erfolfstrüumen, vom Verlangen nach Besitz und insehen, begleitet."107 But this longing for possessions and respect is the catalyst which leads Uli to a virtuous lifestyle and to his own eventual salvation. We need to remember Gotthelf's claim that the earthly and heaverly happiness are attained by the same means. This longing cannot evolve into avarice. Any step in that direction is punished. Avarice, or greed, is, after all, one of the seven deadly sins. 108 When Uli loans out his money with the intention of amassing more, he looses it. When he wants to marry for money, he fails and suffers ridicule.

Cotthelf continually fought against avarice. In writing a report about the comminity of Utzenstorf, we read of Gotthelf's perceptions from Ernst Gallati: "Das normale Verhaltnis zu den materiellen Gutern sei oft gestbrt, etwa bei Ubertriebener Sparsamkeit oder blinder Arbeitswut." 109 What, besides avarice, is "ubertriebene Sparsamkeit"? Gallati quotes many more examples of vice, some relating directly others indirectly to avarice.

Knowing that Gotthelf studied Hegel's dialectical process

$$
107_{\text {Fehr, Das Pild, } 291 .}
$$

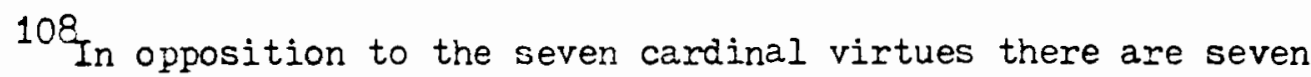
deadly sins or vices "for which punishment is eternal damnation... They are pride, covetousness or greed, lust, envy, gluttony, anger, accidie (or sloth)." Metford, Dictionary of Christian Lore and Letend, 225. 
may help in explaining Gotthelf's fosition. It is possible to say we found Uli early on in a frame of mind which made him wasteful of his resources; that may be our thesis. As Uli realizes the materialistic possibilities before him, he experiences notions of the opposite extreme, those of avariciousness. This is the antithesis. Neither of those extremes is fruitful and Uli comes to a realization of the moderate, and for Gotthelf true, principle in regard to one's disposition toward the material, i.e. the secondary virtue of thrift. This is our synthesis, the newIy discovered truth in Uli's circumstance.

Avarice then becomes the antithesis, or opposite of a virtue, a vice. At the same time it can also be a degenerated virtue (without the effect of another medieval virtue - mâje). Avarice can start as thrift and then grow to an excess. If this secondary virtue, thrift, does not lead to the primary virtue of love of one's neighbor by way of Eenerosity and devoutness, it also cannot lead one to cod and the uItimate purpose of the virtue is lost. Instead of God influencing a Derson, the person is ruled by what was originally virtue, now turned negative in its effect. It turns negative by being carried to an extreme, as in the case of avarice, or it becomes totally meaningless since it does not fulfill its true objective. Greed is an abhorrently exaggerated thrift, an extreme which controls a person in such a way as to act as a barrier between a person and the godly primary virtues.

This is not the case with Uli. He is led into temptation as he considers marriage to Elisi with her potential inheritance as a catalyst. Eut Gotthelf makes it clear that even throughout this time 
U1: thinis about Vreneli. In this way two important factors are presented to the reader: first, that Uli would never have found happiness with Elisi, and in a general sense, that his avariciousness would have stopped the sanctification process; secondly, as cunther so aptly puts it, "Mit Vreneli tritt eine neue bauende Nacht in sein Leben: die Liebe."11C Once Uli regains his perspective and puts any avaricious notions under control, he puts himself in a position to experience the primary virtues. Uli becomes in essence moderate to be able to do this.

Gottheif teaches moderation. The balarce between Heven and Earth has to be kert. Otherwise one becomes too schwämerisch on the one side, which was Gotthelf's opinion of his pietist critics, or too rorlaly on the cther, i.e. materialistic. 111

\section{Vintue Vis-2-vis Materialism}

Is it possible to be simultaneously materialistic and virtuous? Is VIi materialistic? These are questions which must be answered if one is to explain the role of the secondary virtues.

In crder to answer these questions, we must be conscious of the premise that Gotthelf believed in a personal God. Guggisberg gives us the following insight:

Gotthelf steht allen Spekulationen Uber das Wesen Gottes fremd

i10 Werner Glunther, Jeremias Gotthelf: Wesen und Verk(Berlin, Bielefeld, Munchen: Erich Scrmidt Verlag, 1954), 144.

111 Bayer, referring to Gotthelf's biographer, writes: "Manuel wusste also, dass Eitzius den jungeren Fietismus (Erweckungsbewegung) als zlugellose Schwdrmerei bekdmpfte..." Eayer, Theolocische Quellen, 426 . 
gegenllber. Gott ist fllr ihn kein abstraktes iesen, kein

Begriffsgott, Uber den man wie luber irgerd einen Gegenstand reden kbnnte, ohne von ihm nicht in innersten berllhrt zu sein. Er ist flur ihn nur in der Erfahmune zu fassen. Gottinelf spricht nur vpn der Seite Gottes Wesen, die der Welt, dem Leben zugewandt ist. 112 God is therefore directly connected with the world, bein its creator. The human individual, also a creation of God, even though earthly, also has godly aspects. Gotthelf makes it his mission as a writer to engage people with this aspect. Through UIi he shows that God has a direct interest in mankind, that the creation is intimately bound together with the creator. In this sense there is for Gotthelf no separation between physic and metaphysic. The material can be spiritual and the spiritual can be material.

Since God is only comprehensible through experience, this also being an understandable, i.e. empirical attestation of God's love, there are still many people who, not having experienced him, are spiritually separated from lod. So there must be a way in which one may gain experiences which lead to God. In UIi it is the moderate, unselfishly practiced secondary virtues which lead to this path. When Uli saves, he not only has money but also a feeling of security. He can make it through some periods of illness when he can't work; he's more in control of his own life. When he is loyal toward his master, he not only receives a raise in salary but also increases in his feelings of responsibility toward himself and his master. When he acquires humility, the master teaches him techniques of farming. Each secondary virtue that Uli acquires builds his character through

${ }^{112}$ GuggisberE, Christentum, 92. 
positive experiences and lead him toward the primary virtues. From tariftiness comes the hope to better himself. From loyalty comes, in the end, love. Througn devoutnes he gains more and more faith. Which secondary virtues lead to which primary virtues is also at times interchangable. Eut this does not occur until he recognizes through experience who means well with him and that through thrift and loyalty things may be achieved. It is Uli's experiences which prove to him that the virtuous way is the right way, and simultaneously let him experience God.

Because these Christian virtues are given by an exegete of a Christian God, they then also lead to a Christiar Goc. This God, since he involves himself directly, knows how to rewerd vituous behavior. And the one who through this also experiences God, knows how to recognize the reward as God's blessing. It follows then that if one considers material possessions in and of themselves, as long as they are linked with God, Gotthelf is not antimaterialistic. It is a person's attitude toward those possessions which concern him. If God and his commanded virtues are removed from the relationship between an individual and his or her possessions, then fotthelf becomes very antimaterialistic.

Aside from the individual's relationship to material gocds as mentioned above, there exists also the philosophy of materialism. The whole system of exchange of goods and services, i.e. economics, was being revolutionized and affected people's lifestyles. With the economic revolution came new ways of thinking in an attempt to deal with these chanzes and their relationship to some of the furdamental 
questions of human existence, Gotthelf could not accept the resulting philosophy of materialism and many of the changes it reflected. In this he was truly conservative. Uli, being "eine Gabe fur Dienstboten und Veisterleute", people who share an economic relationship one with another, allows us to understand why Gotthelf was so opposed to these changes. He saw the Christian order and therefore the sanctification process threatened through the social and political occurances of this time period. How he understood this order tinreatened will be explained by the next quote. He need to be quick to add that Cotthelf, however, was not a prophet of doon. He believed that the world was progressively gettine better. But he also believed there were eiements which obstructed this move toward betterment, and he fought vehemently against them. If matter, through the virtues, is bound to God, there is a pexceful coexistence. Should matter exlude God, then it degenerates or alienates the secondary virtues and declares war on the primary virtues. One of the socio-political economic systems which did exactly that was communism. Guggisberg explains Gotthelf's consequent position toward this movement very well.

Im ganzen kommunistischen System sieht er nichts anderes als tierische Selostsucht,... Kommunimus und Radikalismus konnten nichts als zerstbren. Diese fahrenden Reuter bildeten zusammen mit $Z$ igeunern und Juden eine Art unheilige Dreitinigkeit... Kommunisten, Sczialisten, Fourieristen und ardere Unchristen suchten die Ursachen des bestehenden Elends nie in der sunde, sondernstets in der bestehenpen Ordnung, ja sogar in den Geboten Gottes und deren Eefolgung. 113

Uli, in its battle for the Christian order was in this sense entirely antimaterialistic. The social problems are to be solved

113 Ibid. , 266-7. 
through the Irristian virtues. Gotthelf recommends savings banks, "Denn er ist davon Uberzeust, dass sich jeder durch rrichtigkeit zum johlstand erheben kUnne," writes Gugeisberg. 114 But Gotthelf's concern is not just for the material well-being but also the spiritual. iherefore, he continually and polemically attacks the antispiritual Zeitgeist. Maybaum, relying on Sotthelf's texts, writes about Gotthelf's attitude regarding the radical movements.

Die menschliche liatur fordert ihre Rechte, sie will, dass ihre Triebe befriedigt werden; da diese aber durch religibse Tugenden un den wirklich gebildeten Geist nicht in Schranken gehalten werden, so entsteht eine Anarchie der Triebe, lnoranung, in welcher der Mensch nicht leven kann. Diese Lehre sei nichts anderes als, "dass, wen es gelliste, eine Sau sein zu wollen", er dem Verlangen auch nachgeben solle. Van erkenne nicht, dass der Ursprung des Unzlticks in der Sunde liege, sondern glaube, dass er in der bestehenden urdnune zu finden sei, und wolle diese sturzen. 115

Yaybaum also shows in more detail how tinis Zeitceist is being fought by Gotthelf because of this atheistic materialism. 116

In no way should we believe that Gottrelf defended the status quo. We must remember that he was also a political activist and published political articles. He recognized the social injustices and worked to erradicate them. However, a totally different cause was attributed to these injustices then the revolutionaries purported. Gotthelf saw as the primary cause of social ills and injustices the lack of Christian virtues, i.e. sin. Uli is in part an answer to these problems. It is written for both Dienstboten and Meisterleute.

$$
\begin{aligned}
& 114 \text { Ibid., } 269 . \\
& 115_{\text {Maybaum, Gottesordnune, } 30 .} \\
& 116_{\text {See Ibid., } 31 .}
\end{aligned}
$$


Johannes, UIi's master, is just as much an example for an employer as Uli is an example for an emplovee. All characters in Uli show how material goods in and of themselves could do nothing for mankind's ultimate salvation. Only in connection with the to-God-leading virtues is the material a positive force in life; otherwise it is only there to satisfy unbridled drives, destroy the character of an individual, and consequently negate that individual's possibility to experience God. Gotthelf saw this very possibility threatened through the philosophy of materialism.

Karl Marx, on the other hand, dic not see the Christian virtues in a positive Iight; he attacked them. Hermann weiss informs us, "Sein in den Jahron unmittelbar vor der kevolution entwickelter Segriff des Klassenkampfes beweist, wie weit ex sich in seinem Denken von den christlichen Idealen der Demut und Liebe entfernt hat."117 Gotthelf sees in this tendency not only a soci $\equiv 1$ revolution but a declaration of war on Christianity and "die von Gott geschaffene 'unabanderliche ordnung'". ${ }^{118}$ Gotthelf values these virtues as positive, because through them the God-willed onder of relationships between human beings exists. Weiss gives us an example: "Im Gegensatz zu Weitling sieht Gotthelf das $\hat{A} l$ mosengeoen der Reichen und die Dankbarkeit der Besitzlosen als einen notwendigen Beitra zum gesellschaftichen Zusammenhalt an." 119 We may go one step further and say that beyond

117 Hermann Weiss, "Vorspiel zur Revolution: Die Bewertung der Demut in den vierziger Jahren des 19. Jahrhunderts." Zeitschrift fur deutsche Philologie 97.2 (1978), 211.

$118_{\text {Ibid., } 220 .}$

110 Ibid., 221. 
the societal bond this seems essential for salvition. It is through personal interaction that virtues can be pricticed; they cannot operate in a vacuum. Nor can they be mediated through government or social agencies. The personal interaction is important as we can certainly observe with UIi and Johannes as examples. Gotthelf did not want a change in this Gottesordnung. The Christian feeling of responsibility toward one's fellow human being has to be developed within each individual and cannot be mitigated or taken over by the state and its agencies.

The spiritual roots of human relations had to also be nourished on the side of the poor. They should know "wer es gut mit innen meine", as is so often written in Uli. The poor also need to stay within the bounds of the to-God-leadine virtues, otherwise there are no more bounds whatsoever. Weiss quotes Gotthelf: "Je unbekannter der Geber mit den Amen ist, desto frecher ihre Forderungen..."120 (This, of course, is an argument which still exists today in any welfare state.) If the poor recoznize, through their gratitude, the goodwill of the giver, the possibility exists that they could perceive the given as God's blessing, i.e. a reward for their humility and gratitude, and not think of it as their right. Through this the virtues agiin lead mankind toward God. Both giver and recepient are sanctified throlgh their virtuous conduct and interaction.

So Uli shows us the right way to salvation. Johannes' exemplary mastership and Uli's becomine teachable, allow both master and servant simultaneously to further develop as Christians. The material is 
both a jait and a reward for virtuous actions.

\section{BIBIICA ETHIC NND DOCTEINE}

In Uli Gotthelf presents a God who is not abstract but inextricably involved with human affairs. He rewards and he punishes. Keller identifies this as jlisisch.

The argument that Uli has Jewish, i.e. old Testament elements should not elicit objectionable reactions from a Christian frame of mind, at least theologically. Christianity's roots are deeply implanted in the soil of Judaism. Both the old Testament and New T'estament are accepted as canonized scripture in the Christian world. An occasional visit to hear a sermon will prove that doctrines are Freached out of both texts, however varied their interpretations might be. In the epistles of St. Faul, perhaps the most often quoted sources of Christendom, we find written: "So ist das Gesetz unser Zuchtmeister gewesen auf Christus, ..."121 Zaul, himself a cofounder of Christianity, or at leist his editors, do not reject the old but view it as preparatory for the new teachings.

Gotthelf has no need to excuse himself for using both the old and the new; both, in conjunction with one another ledd to a Christian God. The commandment to love one's neighbor is not new. It is also in the Old Testament. "... Du sollst deinen Nuchsten lieben wie dich selbst; ich bin der Herr." ${ }^{122}$ The commandment is directec toward the Hebrews but prepares the way for the Christian universalization of the

$$
\begin{aligned}
& 121 \text { Gálatians iii.24. } \\
& 122 \text { Leviticus xix.18. }
\end{aligned}
$$


principle. The old testament is richly endowed with symbolism, metaphors, similies, and other literary devices which have been interpreted by the Christian world as preparations for its message.

\section{The Sanctification Erocess}

Gotthelf saw in the farmer the image of an ideal. Farming without God is for him not a possibility. One is always dependent on Him since He is the creator and ruler of nature, also manifesting Hinself in nature but not in the pantheistic sense. In Uli the sanatification process becomes visible because of this connection between creator and creation. Cunther writes the followine about Gotthelf's Bauernwelt: "Und als ihren kostbarsten und sch bnsten Sinn hat diese geistige Welt ihm Lejenstreue und Lebensreinheit: Heiligung offenbart."123 jli embodies the universal model for the sanctification process as typified through farm life. To be a farmer means being dependent on God. And to be a successful farmer, one has to have a positive relationship with God, i.e. being devout in order to earn God's blessings. Therefore, Uli is led to God trrough the temporal concerns of the farmer which are positively acted upon by the secondary virtues, those building and developing Uli's character to prepare him for the primary virtues and salvation.

To further support this point, Glinther's insight into Gotthelf's Bauernwelt is very helpful.

Vorrecht und Verantwortung, Segen und Pflicht des Bauerntums quellen aus dieser Unmittelbarkeit des Auf-Gott-gestellt-Seins. sie enzeugt die vier Kerntugenden, die, wie Cotthelf anderwärts

123unther, wesen und werk, 45. 
sagt, ein Bauer haben muss und ohne die er keiner ist oder es nicht lange bieiben hird: Arbeitsamkit, Huslichkeit, ihrbirkeit und

This point is presented very vividily when Joharnes, JoEgeli's son, looses the Glunzge ir an auction. The lack of the above mertioned virtues make it impossible for him to be a famer. He regards farmine as unworthy of himself, is sanctification is therefore out of the question for this Johannes. Not only does he personally resist the responsibility which could lead him on the path of saving virtues, but he also tries to dissuade UIi from remaining loyal to Joggeli, his own father, by offering UIi a job and luring him away from the farm. The latter is not dissuaded. In a nore general sense Uli remains loyal to the world of the farmer and with that remains with the sanctification process actively engaged.

This sanctification portrayal never transforms itself into a romantic image of the iajeal. It is not an idyllic minror image of an archtype. This is what makes the work so believable, the realities of farm life are not hidden, not even the vulgar language is excluded, in short, it is not deified or mystified. Gunther writes: "Die Identifizierung von Heiligung und bauerlichem Lebenssinn hat ihn niemals gehirdext, die Eauernwelt in inrer ləbendigen und irdischen Realitut zu sehen." 125 That is why the descriptions of the town brawl, the fightine maids, the mentioning of dung, etc. fll this is a part of farming life that up to now had not been included in any writing about

$$
\begin{aligned}
& 124 \text { Ibid., } 48 . \\
& 125 \text { bid., } 52 .
\end{aligned}
$$


this class of people. In doing so, Gotthelf was one of the first. Consequently, some critics looked at this understanding and showing of the real farm life as having a "worldly" perspective.

Gotthelf, beine a descriptive, or demotic writer, was therein misunderstood. He saw much in human beings which could be termed animalistic. For him, the person who was not on the road toward sanctification was animalistic. This is a person who lives from day to day, doesn't think about an future, is perhaps not even capable of doing so, and does rot fractice the vitues because they have no purpose for slich a person. $U 1$ is in exactly this condition at the beginning of the novel. For him, a poor farm servant, "dem niemanà eine Freude leider will", there is no future.

One might well ask how this conception of the human individual and his or her sanctification process fits into the theological arguments of the time. Eut it is interestine to note that Gotthelf coesn't place much value on theclogical axgunents; it isn't they which sanctify a person, it is the sphere of active Christian virtues, as seen in uli. Jespersen sums it up thusly: "The exegisis of life can never be learned in theological lectures." 126 . Yow one is to live can only be learned through experiencine life itself. This areument is consistant with Gotthelf's view that to know God one has to experience him. Experience, total active involvenent in life, is for Gotthelf essential for eventual salvation.

In order for Uli to be saved, he has to become actively engaged 126 Jespersen, Christian Order, 109. 
in life. Uli sees how well off others are but can in no way experience the goodness of God in his condition. His lifestyle keeps him separated from God. It is impossible for God's influence to penetrate his life, until, through the help of the Eodenbauer, he removes his superficial life experiences and exchanges them for the secondary virtues. Guggisberg describes the frame of mind and reference that Uli had to deal with.

Durch die bittere Not des Daseinskampfes richtet sich die ganze aufmerksamkeit auf das haterielle und der Cenuss. Die eigene Not findet am Luxus der anderen ein schmerzliches Gegenbild. Tan senthnt sich, an der Cberfluche zli bleiben, durch fikohol und Iiebschaften wird das Geflihlswesen verwitstet, die akute Rationalisierung des Lebens macht das Einstrbmer Uberrationaler Krafte unnlglich. 127

This describes Uli perfectly at the beginning of the novel. The superrational powers in this case woula be God, who has no access to Uli in the condition he is in.

When a person finds himself in this condition, Gotthelf shows that such a person carnot only not be helied by God but cannot help him or herself either. The only one who is thus capable to help is someone who is already a true Christian, i.e. is on the level of the primary virtues and has a positive relationship with God. In this novel that role is filled by Johannes, the Eodenbauer. Of him Sengle writes: "Die Zustande, in denen Uli lebt sind nicht nur normal, sondern glnstig, dadurch vor allem, dass sein Chef, der Bodenbauer, ein 'wahrer' Meister ist, ein Idealbild aller Tugenden."128 This Johannes 127 Guggisberg, Christentum, $263-4$.
$12 \varepsilon_{\text {Sengle, Eiedermeienzeit, }}$.1. 
was tole to influence Uli in that he was already on this "advanced" level. Niever dia he give theological lectures to Uli, only addressing those points that were pertinent to Uli's life whenever he gave him a lecture of any kind. Other than that, he simply let lili experience his own goodwill. Only in tris way does Uli discover, efter many events, "wer es gut mit ihm meine". Johannes leads him toward the sanctification process. One's fellow man is absolutely essential to find the right path. Cn his on her own a person carrot be saved. Therefore, every individual has a direct resconibility toward his or her fellow human being. This point is adaressed by laykaum.

Das Gebot der Nüchaterliebe weckt nicht nur Iiebe, sondern damit zusamien Verutwortungsbewusstsein. Es ist eine verwerfliche Einstellung, wann jemand sagt, ihn gehe "die ginze Sache lizchts an, und, was ihn nichts angehe, darein mische er sich richt".

Johannes' neighbor, Resli, does not have this feeling of responsibility toward others. He allows his servants to have relationships as though they were married. Consistently he is plotting how to dismipt any positive relati nship between Johanies and $\mathrm{U} l i$, almost succeeding on occasions.

Johannes, however, becomes UI:'s protector, one might say God's proxy. "Denn die Art, wie Johannes seinem Knecht gegentbertritt, wird allein von der christlichen kgave bestimmt," writes Fehr. ${ }^{130}$ Fehr also goes on to describe the effect of Johannes' actions. He helps Uli toward "der selbststunaigen Entfaltung der innewohnenden Krafte". 131

129 Maybeum, Gottesordinung, 73.

130 Fehr, Das

131 Ibid., 26?. 
For Uli, it is his relationship to Johannes which helps him in his socio-economic betterment. To the young servant the sanctification process is not a consciously chosen road but rather an adherent of economic progress. At the start Uli can only see the ladder toward material success; he does not yet know that it is a double ladder, the other leading to spiritual success, or happiness.

When one has this feeling of responsibility toward one's fellow nan and practices love of one's neighoor, then it is advantageous to be meterially in a position to give hel: and to reward. In Uli's case this is very important since his material progress is bound together with his spiritual progress. Gotthelf's attitude toward material goods cannot be overemphasized. Here we need to recognize that a wealthy or well-to-do person need not sell everything he or she has and give it to the poor, as is written in the Biole. Gotthelf sees this as impractical and ineffective in the lone range. Jespersen says it thusly:

In all of Gotthelf's works, there is not a single example of a person who believes that it is necessary to forsake wealth and material comfort in order to be a cood Christian. It is sufficient that he use his worldily possessions unselfishly to promote righteous causes. 132

This reiterates the quote in the last part of the preceding chapter when the minister speaks. It is what one does with one's possessions that is the crucial factor. If they are used to help one's fellow man, then it is good. Are they used to satisfy animalistic egotism, then it is bad.

132 Jespersen, Christian Oràex, 89. 
The princinal egoists of the work: Elisi, Joggeli, Johannes (Jogeli's son), and tha cotton merchant are examples of the negative disposition. There exists also no spari. of hope of a spiritual bettement.

The strong Stamm on which Uli raises himself has to evertually be left by him, if he wants to make progress. Not only does Uli in his new position receive a higher salary but also more responsibility and effect on the lives of other poople. He must become more independent. The acquired virtues become solidified and he nears God through his experiences, until at the end, when he, with the love of Vreneli, is in hesven.

Later in the work Vreneii becomes UII'ミstrone Stamm on which he continues to raise himsels. Someone has to always be there with whose help progress is possible. Gotthelf looked at the human race as dynamic, always beconing better. "Wir Menschen alle, Erediger und Laien, sind ein ierdendes, unz wo Leber ist, da ist ein ierden bis zum Tode..." This we read in a letter by Gotthelf as quoted by Neuenschwander. ${ }^{133}$ Even though the Hegelian influence can definitely be felt in this quote, it relates directly to the sanctification process.

Virtues can only cperate in a social context. It follows then that Uli, or anyone else, can only be saved through interaction with other people. Asceticism has no place in Gotthelf's sanctification process. It should be clear then that the biblical doctrine of love of one's neighbor, through johannes, is what promotes Uli on the path of 
biblical ethic, i.e. secondary and primary virtues. These enable him to experience the love of God and to replicate it on the human level through his interaction with others. The formula for the process can be summed up thusly: a Christian individual helps promote someone to the with material reward connected level of secondary virtues, these lead to the God connected primary virtues.

\section{nork And Accuisition}

The roots of the Christian work ethic are alreidy deeply embedded in Hebrew literature. "In the sweat of thy sace shalt thou eat bread, ..."13t But to say, as Keller did, $\underline{\text { Ui }}$ is more Jewish than Christian, shows to some degree naivety about or nonacceptance of Cotthelf's beliefs, which leads to false conclusions. Gotthelf himself did not value Jery very highly, which is a reflection of a fan-wuropean atiitude of the time.

For Gotthelf, the children of idam and Fve are in the same condition as concems work as their ancient father and mother. Each individual must or should work to sustain him or herself. Fhysical sustenance is an aspect of life that is the responsibility of the individual. This aspect fulfills its true and God-given purpose only if it is connected with a restoration of an intimate relationship with God, which was lost do to the fall of man. This means that work becomes a catalyst in the sanctification process. The welfare state was, for Gotthelf, the antithesis of one of God's commandments. Commurist and socialsit doctrine were not just anti-Christian in their 
aetheistic teachines, but also interfered in the Christian realm of action and made it impossible to experience God and his blessings through work rewarded by him. The ideology becomes the new God, the state the mediator, or Christ. Work would be tied not to a religious God in the conventional sense but to ideology. This is intolerable for a man who believes that through work, especially farming, one can come to experience God.

Work and acquisition are esvecially for lil a material sim of spiritual progress. We have to be careful not to confuse this with Calvinism. lrothingis absclutely predetermined, and material posseisions do not unequivocally mean that he is rich due to the pleasure of God. Gotthelf does not accept the doctrine of predestinäion; it is trroliek recognition, conversion, work, and progress that mankind is sanctified.

Ferhaps we cannot imagine an individual within a society who does rot in some degree fit into the category of either master or servant, employer or employee, for whom these principles could not be applicable. Then one thinks of the welfare rolls and the unemployment lines. Gotthelf perceives an increasing difficulty in a modern industrial society to retain the intimately personal relationsnips of employer and employee, those relationships that allow for a feeling of direct responsibility and love for one's fellow man. The masses of workers in a factory have little or no personal contact with their employer, who often values the worker as part of an abstract resource with the term "labor force". Gotthelf did not only see a danger in the comunist reaction of the proletariat but also in the entire capitalist 
industrial revolution. The life of the Emmental farmer for him was what shaped his beliefs and uli serves as a reflection of those beliefs. Iis was a voice of century old stability in a revolutionary worla.

\section{The Economy}

Otto Brunner gives us a better insight into why Gotthelf uses the model of the farming world to express his religious beliefs. He writes about economy.

Die Okoromik ist buchstublich Lehre vom Cikos, von Haus im umfassendster Sinn, vom "ganzen Haus", um mit Hihelm Heinrich RiehI zu sprechen, der diese heute nur noch im büuerlichen Leber teilweise iebendiger Sozialgebilde in Moment seines Zerfalles oder doch seines Zurucktretens beschrieben hat. 135

Eiblically, this "ganze Haus" is the house of hbraham, Isaac, and jacob, as well as other anciert patriarchs, and in this sense is hebraic. These ancient housefathers did not on ly have responsibility for the income and care of their own nuclear or extended family but for an entire economic society. Their word is to be obeyed. Through them come the laws, the rules of behavior and control of relationships between all those belonging to the house, as well as all decisions concerning the econony of the house. The sphere of influence of such a houserather is allencompassing, affecting all areas of life. is such, the housefather had to act in the interest of the entire household. He would not be successful economically if his attitude were selfish or self-serving. Erunner further explains:

1350 to Erunner, "Itas Eanze Haus und die alteuropulische ckonomik," in lieue Wege der Verfassungs-und Sozizlzeschichte. 2nd ed. (Gyttingen: Vandenhoeck i Muprecrt, 1956), 104. 
Die Cikonomik als Lehre von Oikos urfasst eben dio Gesamtheit der menschlichen Beziehunzen un matigheiten im Hause, das Verhultnis von Hann und Frau, Eltern und Kindern, Hausherrn uni Gesinde (Stiaven) und bie Erflillune der in Haus- und landwirtschaft gesteliten dufgaben. Er ist notwerdis und erlaubt, soweit er der Hreurzun der hutarkie des Hauses lient, er ist verwerflich, sobald er zun, selbstzweck wira, das heisst, auf Gelderwerb an sich zieht. 35

This doctine is built into lil. Gotthelf believes this situation is still found in the farming life of the Emmental. Johannes, the Eodenbauer, is such an idea? image of a housefather whose concern is for the entire house, not only his immediate family or even just himself. He is necessary ana allowed because he does not only work for and toward his own interest but that of his entire house. Therefore, he is also concerned with what $\mathrm{Uli}$ does with his free time. Invariably it is a reflection on his house, and havins responsibility toward all its members, this also includes Uli. Johannes then, in a very real sense, becomes Uli's father. This feeling of responsibility is addressed in the text itself. "Die Meisterleut sind doch Meister in inrem Hause, und was sie in ihrom Hause dulden, und was sie ihren Leuten nachlassen, dafur sind sie Gott und den Menschen verantwortlich." 137

Athough having links to the Hebrews, such a conception is not exclusively hebraic. According to Brunner it is a tradition which, through the Greeks, was also old-European.

Die alteuropaische Okonomie ist die Lehre von der "Wirtschaft" in buverlichen Sinn, vom "ganzen Haus". Was seit lien Griechen im europalischen Jenken theorstisch erfasst wird, ist eine sehr

$$
\begin{aligned}
& 136 \text { Ibid, } 105 . \\
& 137 \text { Gotthelf, Samtliche verke, 4:3. }
\end{aligned}
$$


viel weiter vorbreitete Denkweise, die der Grundform aller Bauernkulturen entspricht: Las Haus, die Wirtschaft ist das gmandiesende Sozi三lgebilde aller büuerlichen uni bauerlichadelizen Kulturer... und wurde in diesen Jarrtausenden vor

Strukturwandel der polifischen Formen der Oberschichten in seiner Substanz wenig Derthrt. 138

During the time Gotthelf was writing, the age of industrialization, this old-European faming economy was still very strong in the

Emmental. Secause of this commonality among all farming cultures, this "entire house" economy, it is very plausible to find among the Emmental farmers an econony winch is also found in the Eible, especially tine pastoral Cld Testament settings. The biblical patriarchs, as models of a lifestyle direotly suborainate to God, could find their replica in the farmer of Cottnelf's world: specifically is it the Eodenbauer in $\mathrm{UIi}$

We already examined Johannes' role as God's proxy. His virtuous actions influence VIi in the way they do because of Johannes' advantigeous position of a biblical housefather. The virtuous administration of the "entire house" enables him to teach and reward UIi. He gives UIi experiences, through the secondary virtues, which lead him to the primary virtues and to God. In this fashion Johannes is God-like, not only in the old Testament kind of way but also in the Christian. As such a human representation of God we see characteristics which reaffirm the Christian perspective. Johannes is God-like in that, as the administrator of the "entire house", he loves, teaches, and rewards, i.e. is actively involved as a positive force for good. This connection between Johannes and his house and God and his world is not 
somethine new. Emuner clarifies this:

Is whre aber durchaus ingrich, das die eliteren Jarrhunderte boherrschende religibse Geschichtsbild, die christliche Geschichtstheologie "Hkonorisch" zu nernen. Denn "Oeconomia" ist auch ein Terninus dex christlichen Dogmatik seit Tertullian, meint die die Geschichte bestimmende gttliche Veltregierung, den Heilsplan. Noch in einen Huptwerk der Hausvaterliteratur des 17. Jahrhunderts, in Wolf Hehnhards von Hohlbere "Georsica curiosa" heisst es in cer Einleitung, dass Gott "der menschenliebende, himnlische Hausherr sei, der nicht ablusst, die grosse Weltoeconomiam noch immerdar $z u$ bestellen und zu regieren". Man war sich also damals des Zusamerhangs zwischen g"btticher und menschlicher "Mronorie" noch wohl bewusst. 139

We are already familiar with Gotthelf's idea that heaven is bound closer together with Earth than is generally believed. How much

Gotthelf knew about or was directly influenced by the Hausveterliteratur may be a question for further study and research. A knowledge thereof would not have been necessary though to create U1: in that tradition. It was a cultural and not just a literary tradition and therefore can be experierced in life if not read in books. Ne know how Gotthelf felt about experiences. This viewpoint about economy, for Gotthelf perhars more intuitive than conscious, is a fact of his farming world.

\section{Gotthelf's Christianity}

Gotthelf was a practical person who did not value the theoretical very highiy. He did want to actualize certain ideals but had no unrealistic illusions. Eecause of this practical disposition, he also had not much use for abstract theology. What was theolocically Christian had less meaning for him than what was pragmatically applicavly Christian. Therein lies also the origin of his sociopolitical activism, which he practiced very polemically. It is this

$$
139 \text { Ibid. , } 126 .
$$


practical Christianity which helps Uli to be sanctified. It is not his going to church and having his mind theologically engaged with doctrine and dogma. What Bayer says about another work of Gotthelf is also applicable here. "hie auch sonst in der Epik Gotthelfs sind hier Geistliches und Weltliches enE miteinander verflochten."140

As a practical man, minister and author, the secondary virtues were of great importance to him. They determine the actions which are labeled as either Cnristian or unchristian. For Gotthelf these concepts of virtue are not just theoretical conversation pieces but tools to be used not only in building a better life for oneself also for others. Gotthelf shows a ral conviction, a religicus conviction toward the role of these virtues. Speaking of the most dominant of these virtues in U1j, loyalty, Hans Eayer, who saw much that wes Waldensian and Eactist in Gotthelf, writes: "Die Fredigten Cotthelfs lassen erkennen, dass diesex Treuebegriff fur den Pfarrer Bitzius nicht bloss eine literarische Fiktion, sondem reales Ethos ist." 141 This total immersion in these concepts is not just true of loyalty but all other secondary virtues in Uli. It must be true because Gotthelf based the process of sanctification on these same secondary virtues, making them indispensible for salvation.

What then is the essentially Chritian in Uli? It is the God representing, virtuous Johannes, the teachable Uli; it is the

140 Hans Bayer, "Biblisches Ethos und bauerliche Lebensform. Die sprachlichen, sozialen und religilsen Gmindiagen von Gotthelfs Epik," in Jahrbuch des Freien Deutschen Hochstifts 1980, ed. Detlev Luders, (Tubingen: Max ifiemeyer Verlag, 1980), 351.

141 Ibid., 356. 
secondary virtues which help $\mathrm{uli}$ on his way toward sanctification; loyalty, thrift, obedience, etc.; it is the primary virtues which allow UIi to experience agape, as well as faith in himself, in God, and in his fellow man; it is the eventual unity with God and his blessing for a righteous life. Uli receives these blessings in this life, not just the next. This is Gotthelf' practical Christianity, it not only helps one achieve a future better world after life, but it can also create a better world here and row; for the individual as well as the entire society. Uli shows us the way to a better world. The work contains prircipies of ruman relaticne which we can all understand and which have universal apyication and implications. This is the Christian and also eternaI ir $\mathrm{U} I$.

\section{REFIENTONS}

In the first chapten the thesis was introduced and presented as a furction of the secondary virtues to lead mankind to the primary virtues and to God. The second chapter dealt with the text of Uli, using the text-immanent method of interpretation. Through thrift, loyalty, industricusness, devoutness, and other virtues, Uli becomes faithful, hopeful, and loving. In the third chapter we researched some of the secondary literature and various aspects which influenced this realm of virtues and have hopefully thereby lent a degree of believability to the thesis.

One thing remains: to address the relevance of all this writing. We are thorourhly conscious of the fact that this thesis could either collect dust on a shelf, or if read, could be the topic of some brief 
discussion and thereby remain irsignificant in its overall effect on the stuicies of Gotthelf. If that occurs, this work will not have any relevance.

Hopefully, in the spirit of Gotthelf, this work will do more than that: ramely, stir up some action. If this thesis has raised some questions which could stir interest in Gotthelf, his writings, and perhaps the topic of virtues in Iiterature as a whole, then the work will have been useful.

There are many topics worth investigating, A comparison between Gotthelf's intentions in writing and today's proliferation of self-help Iiterature would be a worthwhile topic of research; especially if one were to examine the virtues in that literature and the role they play.

The whole idea of progress could be examined, especially the theological and sociological forces which influence this notion. Uli offers us a viewpoint of life which, if acted upon, could enable us as humanity to make greater progress. It is an artistically clothed epic which serves as an exhortation for human progress, which is synonymous with sanctification by Gotthelf. He also stands somewhat outside of the main theological movements. Hans Eayer researched Gotthelf's theological sources. A comparison between Gotthelf, church dogmas, and exegetes of his time would also prove interesting.

Then there is the topic of the secondary virtues in general. Loyalty, for example, could be traced into the old Germanic epics. Germanic loyalty could also be compared with Christian loyalty. Is it possible that in actuality Gotthelf occupies himself with old Germanic rather than Judeo-Christian concepts of virtue 
in $\underline{\text { Uiz? }}$ ?

In a more general sense, the secondary virtues are also important for the studies in German literature that are in any way concerned with values. This is especially the case with the studies of the Nazi era. Some of the virtues were highly valued, such as loyalty, but had a negative overall effect. They were no longer linked witi Christianity or the pximary virtues. To trace these virtues through the irazi literature would tell us much about the relationship of secondary and primary virtues and their contexts.

At the end of this work, we would be amiss to doubt that Gotthelf was a Christian author. Iike Johannes, the Eodenbauer, says, everything depends on faith; but action leads to faith. Is Uli worldly in the sense of larxistic materialism? ivever. Is Uli worldy in the sense that there is a definite unity between Heaven and Earth tinrough the sanctification process? Most definitely. It is the Christian message that engages Gotthelf, that forces him into action; no fanaticil theclogy or disposition, but a message strongly rooted in the world of his Emmentaler famers. It is sociologically relevant. It is timely, in that the dangers of the industrial revolution are presented through a portrayal of their antithesis. It is individually relevant because of the deep and complete recognition of human nature which one has to learn to control.

In Uli Gotthelf is simultaneously sociologically, politically, economically, and religiously active because the realities of life are not shunned by him. For Cotthelf, the true Cheistian is active; active through the secondary virtues, motivited through the primary 
virtues, and rewarded through a unity with God which in Uli is visible, i.e. empirically verifiabie.

Finally, it is hoped, that this work will make Uli more accessible for some, that UIi will be read in the way that Gotthelf's intuition sensed and felt the work. What primarily makes UIi relevant is that the work deals with some key questions of existence and human interaction. This will make uli relevant for a long time as a valueble artistic contribution to the world of literature. 
Works Consulted

Alger, Horatio Ir. The Train Eoy. Leyden: Aeonian Press, Inc., 1975. Bartels, Adolf. Jeremias Gotthelfs ausgewhhlte Vierke in zehn BHnden.

Leipzig: Max Hesses Verlag,, 1908. 1:68-71 and 2 . Earthel, Helene. "Der Emmentaler Bauer bei Jeremias Gotthelf: Ein

Beitrag zur bauterichen Ethik." In Verbffentlichurfen der volkskundlichen Kommission des Provinzialinstituts fur westelalische Landes-und Volkskunde. No. 3. Munster in Westfalen: Verlag der Aschendorffschen Verlagssuchhandlung, 1931.

Bayer, Hans. "Biblisches Ethos und bauerliche Lebensform. Die sprachlichen, sozialen und religibsen Grundlagen von Gotthelfs Epik." In Jahrbuch des Freien Deutschen Hochstifts 1980. Ed. Detlev IUders. Tubingen: Max Niemeyer Verlag, 1980, 347-402. Bayer, Hans. "Theologische guellen und epische Gestaltung: Gotthelfs 'idezler Pietismus'." In Deutsche Viertel jahrschrift fur Literaturwissenschaft und Geistesgeschichte 54 (1980): 423-63. Brunner, Otto. "Das ganze Haus und die alteuropäische Ökonomik." In Neue hese der Verfassunfs- und Sozialgeschichte. 2nd ed. GBttingen: Vandenhoeck \& Ruprecht, 1968. Durrenmatt, Peter. Schweizer Geschichte. Zurich: Schweizer Druck- und Verlagshaus AG, 1953. Fehr, Karl. Das Bild des Nenscher bei Jeremias Gotthelf. Frauenfeld: Verlag Huber \& Co. AG, 1953. 
Freytas, Custav. Sol1 und Haben. 85th ed. Leipzig: Verlag von S. Hirzel, 1916.

Fricke, gerhard and Klotz, Volker. Geschichte der deutschen Literatur. 15th ed. Lubeck and Hamburs: Matthiesen Verlag, 1971.

Frye, Northrop. The Great Code: The Bible and Literature. New York: Harcourt Erace Jovanovich, Fublishers, 1982.

Gallati, Ernst. "Jeremias Gotthelfs Gesellschaftskritik." In Yanadische Studien zur deutschen Sprache und Literatur, 1. Ed. Armin Arnold, Michael S. Batts and Hans Eichner. Bern: Herbert Iang, 1970.

Gotthelf, Jeremias. Sumtliche Jerke in 24 Banden. Ed. Rudolf Hunziger und Hans Bloesch. Vol. 4. Erlenbach - Zurich: Eugen Rentsch Verlag, 1921.

Guggisberg, Küt. Jeremias Gotthelf: Christentum und Leben. Zurich und Ieipzig: Max Niehans Verlag, 1939.

Gluther, Werner. Jeremias Cotthelf: Wesen und Werk. Berlin, Bielefeld, Munchen: Erich Schmidt Verlag, 1954. Glinther, Werner. Neue Gotthelf Studien. Bern: Francke Verlag, 1958. Hahl, Werner. "Gesellschaftlicher Konservatismus und literarischer Realismus." In Realismus und Grlnderzeit: Nanifeste und Dokumente zur deutschen Iiteratur 1848-1880. Vol. 1. Stuttgart: J.B. Metzlersche Verlagsbuchhandlung, 1976.

Hahl, Werner. "Jeremias Gotthelf: Uli der Kecht (1841). Die christliche "Ökonomik' als Roman." In Romane und Erzlhhlungen des burgerlichen Realismus. EG. Horst Denkler. Stuttgart: Philipp Reclam jun., 1980, 9-25. 
Jesperson, Robert Cliffora. "Jeremias Gotthelf and the Christian Order: A study of Gotthelf's Social Philosophy as it Relates to his Theology." Diss. Stanford 1966. Keller, Gottfried. "Jeremias Gotthelf." In Samtliche Werke und ausgewählte Briefe. Muncher: Carl Hanser Verlag, 1958. 3:916-68. Naybaum, Joseph. Gottesordnung und Zeitgeist: Eine Darstellung der Gedanken Jeremias Gotthelfs Uber Recht und Staat. Bonn: H. Bouvier u. Co., 1950.

Metford, JCJ. Dictionary of Christian Lore and Legend. London: Thames and Hudson Lta., 1983. MuschE, Walter. Cotthelf: Die Geheimnisse des Erzuhllers. Munchen: Verlag C.H. Beck, 1957.

Muschg, Walter. Jeremias Gotthelf: Eine Einfuhrung in seine Werke. 2nd ed. Bern und Mtinchen: Francke Verlag, 1960. Muschg, Walter. Jeremias Cotthelfs Fers bnlichkeit: Erinnerungen von Zeitgenossen. Klosterberg, Basel: Verlag Benno Schwabe \& Co., 1944.

Neuenschwander, Martin. Jeremias Gotthelf als Dichter der Ordnung. Zurich: Juris - Verlag, 1956. Sengle, Friedrich. "Albert Bitzius, pseud. Jeremias Gotthelf (1797 1854)." In Biedermeierzeit: deutsche Literatur im Spannungsfeld zwischen Restauration und Revolution $1515-1848$. Stuttgart: J.B. Metzler, 1980. 3:888-951. Steiner, Enst. Individuum und Gemeinschaft bei Jeremias Gotthelf. Diss. Eern 1954. GrosshHchstetten: Duchdruckerei Jakob, 1954. 
Waidson, Herbert Norgan. Ieremias Gotthelf: in Introduction to the Swiss :ovelist. Cxford: Elackwell, 1953; rpt. Nestport: Greenwood Press Publishers 1978.

weiss, Hormann F. "Vorspiel zur Revolution: Die Eewertung der Demut in den vierziger Jahren des 19. Jahrhunderts." In zeitschrift fur deutsche Fhilolozie 97.2 (1978): 204-25. 